WHOI-89-3

\title{
FASINEX \\ (Frontal Air-Sea Interaction Experiment) Moored Instrumentation
}

\author{
by \\ Richard P. Trask \\ Jerome P. Dean \\ James R. Valdes \\ Craig D. Marquette \\ Woods Hole Oceanographic Institution \\ Woods Hole, Massachusetts 02543
}

February 1989

\section{Technical Report}

\author{
Funding was provided by the Office of Naval Research \\ under contract Number N00014-84-C-0134. \\ Reproduction in whole or in part is permitted for any purpose of the \\ United States Government. This report should be cited as: \\ Woods Hole Oceanog. Inst. Tech. Rept., WHOI-89-3. \\ Approved for publication; distribution unlimited.
}

Approved for Distribution: 
List of Figures iv

List of Tables v v

I. INTRODUCTION 1

II. The VMCM in FASINEX

A. Introduction 9

B. Propeller Bearings 10

1. Bearing Material and Design 11

2. Cage Redesign 17

3. Bearing Performance 20

C. Flooded Stings 22

D. Propeller Detection Failures 22

E. Temperature Sensor Time Constant 23

F. Calibrations and Corrections
to the Temperature Data

G. Standard Cage Strength Tests 26

III. The VAWR in FASINEX
A. Introduction
B. Wind speed, Direction and Velocity 31
C. Direction Comparison Tests 36
D. Temperatures 39
E. Insolation 41
F. Barometric Pressure 46
G. Relative Humidity 50 
IV. The VACM in FASINEX

A. Introduction 53

B. System Temperature Tests 54

V. Acknowledgements 56

VI. References $\quad 57$

VII. Appendix 


\section{ABSTRACT}

In 1986, FASINEX, a Frontal Air-Sea Interaction Experiment, a multi-investigator cooperative experiment, was conducted to study the role of horizontal variability in air-sea interaction in the persistent front formed in the subtropical convergence zone south of Bermuda. Aimed at investigating all aspects of the atmospheric and oceanic variables related to the formation and maintenance of the front, an array of meteorological and current meter moorings was deployed by the Woods Hole Oceanographic Institution Buoy Group in 5400 meters of water. Two subsurface current meter moorings were deployed in october, 1984; five surface meteorological and current meter moorings and four Profiling Current Meter (PCM) moorings were set in January 1986. All except one PCM mooring, which was lost, were recovered in June 1986. This report discusses the extensive preparations of, and modifications to, the Woods Hole Oceanographic Institution Buoy Group instruments placed on the five surface moorings. The equipment included 30 vector measuring current meters, ten vector averaging current meters and five vector averaging wind recorders. 
Figure 3. A composite plot of the Argos derived 6 surface buoy positions and anchor positions of the four PCM moorings
Figure 4. VMCM sting and cage tow tests

Figure 6. Temperature sensor time constant response curves

Figure 7. VAWR wind speed and direction sensors

Figure 8. FASINEX surface buoy with meteorological

Figure 9. Temperature difference histogram: VAWR

sea temperature @ $0.7 \mathrm{~m}$ deep $10.25 \mathrm{~m}$ below buoy hull) minus ten-meter deep VMCM temperature. Total of the values from four FASINEX moorings

Figure 10. Temperature difference histogram: VAWR Sea temperature @ 0.7 meter deep $10.25 \mathrm{~m}$ below buoy hull) minus VAWR sea temperature @ $1.7 \mathrm{~m}$ depth ( $1.25 \mathrm{~m}$ below the buoy hull) from one BIOWATT surface mooring deployment of three months duration (Feb. to May 1987) 
Table I. Anchor Positions of FASINEX Moorings

Table II. Accelerated Wear Tests of VMCM

Ball Bearings

Table III. Sleeve Bearings Tested

Table IV. VMCM sting Acceleration and

Displacement

Table V. Summary of Meteorological Sensor Specifications

Table VI. Meteorological Sensor Heights

Above the Buoy Waterline

Table VII. Flow Direction as Measured by

VAWRs in Calibration Tests

Table VIII. VAWR Bath Test Results

Table IX. Atmospheric Pressure Comparisons

Table X. VACM System Temperature Tests 



\section{Introduction}

Early in 1983 meteorologists and oceanographers attending an air-sea interaction meeting at the National Center for Atmospheric Research (NCAR) identified the need to investigate the role of horizontal variability in air-sea interaction. Subsequent discussions focused on the advantages of conducting such an experiment near an oceanic front similar to those found in the subtropical convergence zones of the North Atlantic or North Pacific. With time, plans were formulated to conduct a multi-investigator, cooperative experiment in the subtropical convergence zone in the Atlantic south of Bermuda within the area bounded by $68^{\circ}$ and $72^{\circ}$ West Longitude and by $25^{\circ}$ and $28^{\circ}$ North Latitude (Figure 1). The major field program started in January 1986 and ended in June 1986. Because of the choice of an oceanic front for the site of the field work, the experiment was given the acronym of FASINEx (Frontal Air-sea Interaction Experiment).

The field experiment was aimed at studying the lower atmosphere, the upper ocean and the interaction of the two in the vicinity of a subtropical oceanic front. The scientific objectives as summarized by stage and weller (1986) include investigating "the role of atmospheric forcing in maintaining the subtropical front; changes in surface roughness, stress, and drag relationships across the front; the impact of clouds on the vicinity; mean marine-atmospheric boundary-layer structure in the area; life cycles of turbulent structures near the front; surface forcing of the upper ocean by the atmosphere in the presence of sea surface temperature and oceanic velocity inhomogeneities; the structure of the oceanic front; and the role of horizontal variability in air-sea interaction processes." 


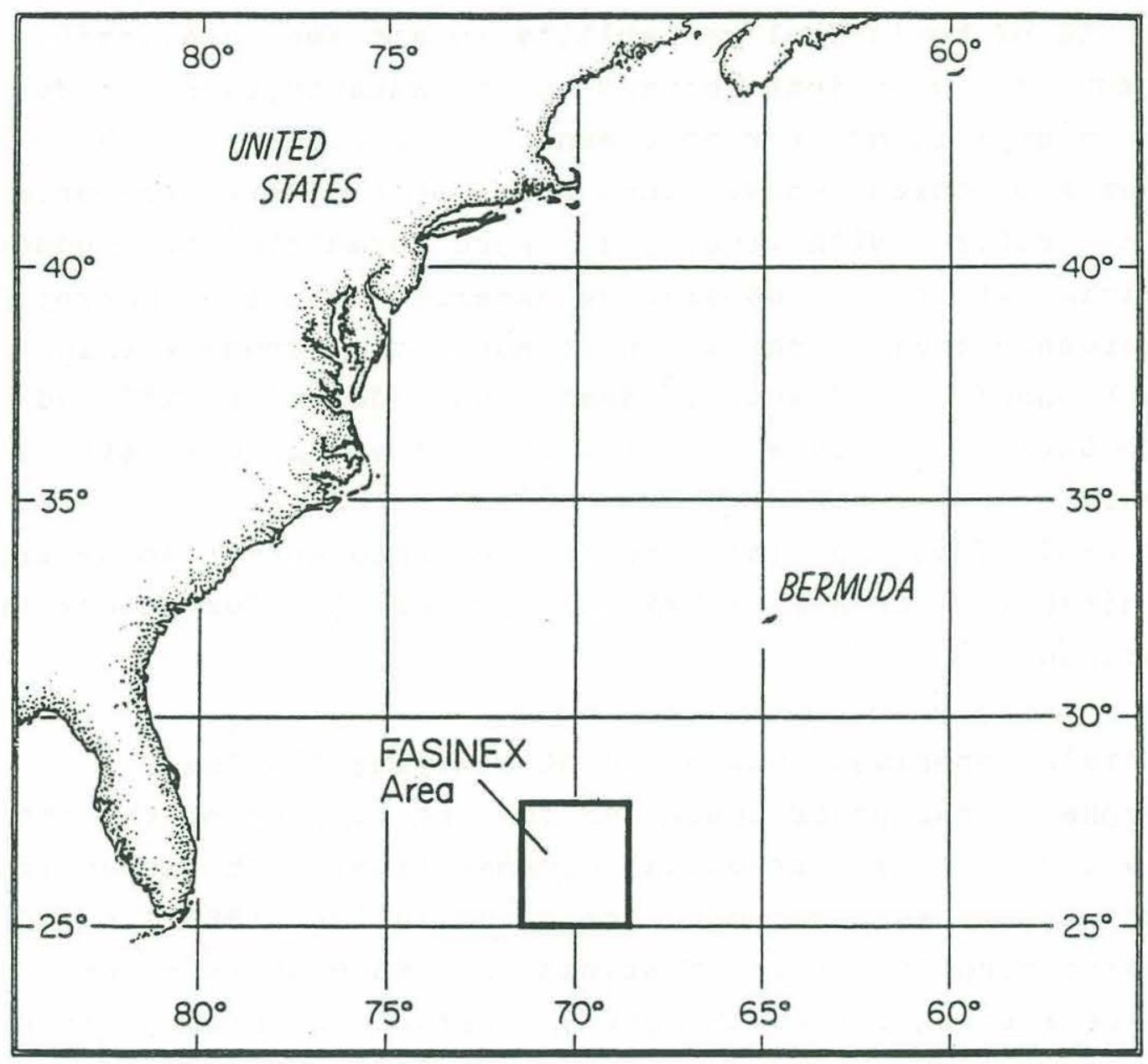

Figure 1. Location of FASINEX area 
To address several of the oceanographic objectives, an array of five surface and two subsurface moorings were deployed in support of work proposed by Woods Hole Oceanographic Institution (WHOI) investigators (Stage and Weller, 1985 and 1986). In addition, four Massachusetts Institute of Technology (MIT) Profiling Current Meter (PCM) moorings were also deployed. The surface and PCM moorings were deployed near $27^{\circ}$ $\mathrm{N}$ latitude, $70^{\circ} \mathrm{W}$ longitude from January to June 1986 in 5400 meters of water. The subsurface moorings were deployed in October 1984 and recovered at the same time as the others in June 1986. The subsurface moorings were located approximately one degree to the north and south of the surface mooring array. Anchor locations for all the FASINEX moorings appear in Table I. Of particular interest here are the surface moorings and their instrumentation, prepared, deployed and recovered by the WHOI Moored Array Project, better known as the WHOI BuoY Group.

Buoy Group instrumentation placed on the five surface moorings included 30 Vector Measuring Current Meters (VMCM), ten Vector Averaging Current Meters (VACM) and five Vector Averaging Wind Recorders (VAWR). Other instrumentation on the surface moorings included four Scripps Institution of Oceanography (SIO) VMCMs loaned by R. Davis; five WHOI Meteorological Recorders (MR) supplied by R. Payne; and one WOTAN (Wind Observations Through Ambient Noise) instrument supplied by W. Large of NCAR. A photograph of the surface buoy from mooring F2 (Figure 2) shows the configuration of the meteorological sensors mounted on the tower of the three-meter diameter discus buoy. Each of the FASINEX surface buoys had an Argos satellite transmitter which provided buoy position information during the experiment. Figure 3 is a composite plot of the FASINEX array showing the Argos buoy positions and the anchor positions of the four PCM moorings. 


\section{Table I}

\section{Anchor Positions of FASINEX Moorings}

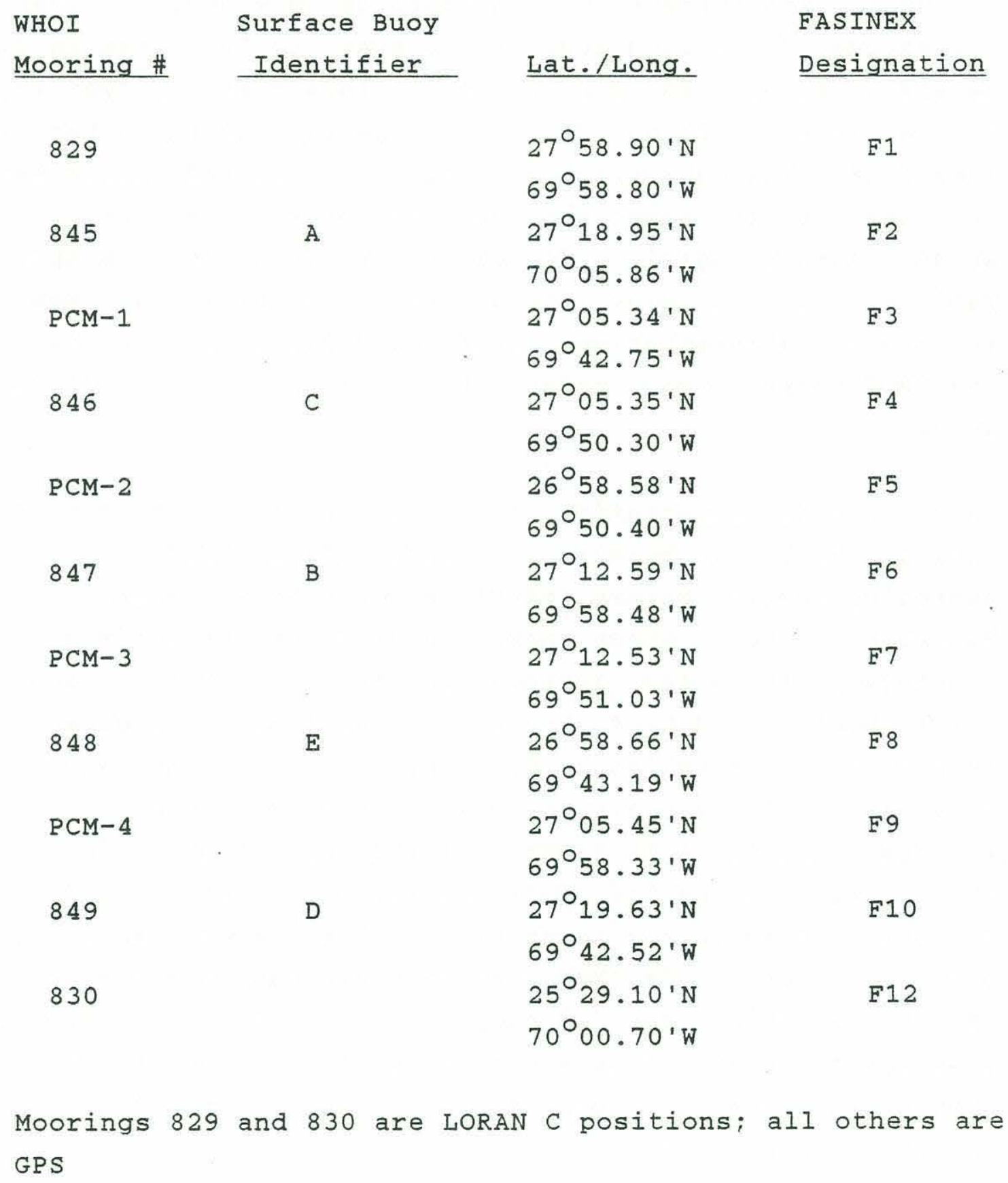




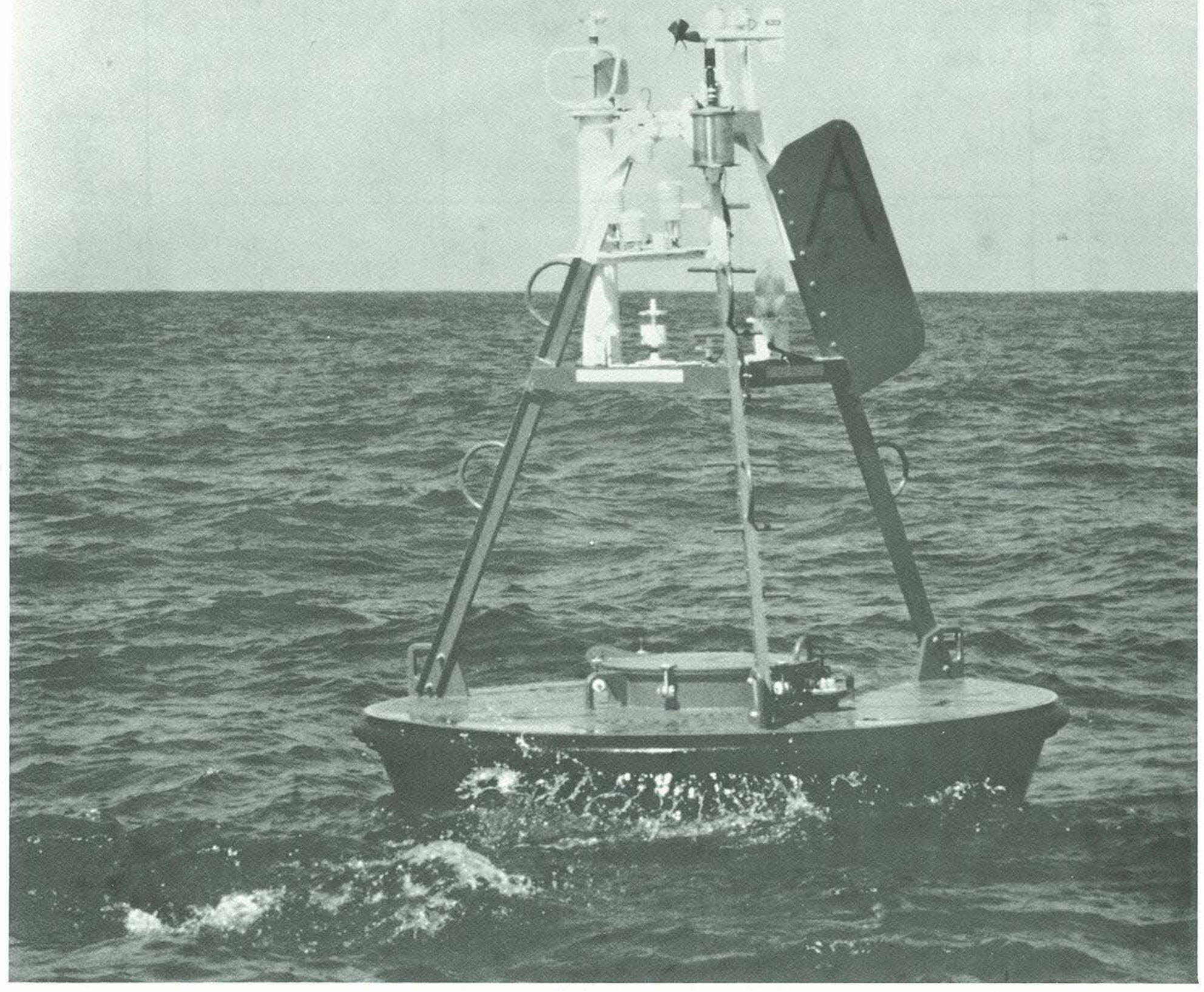

Figure 2. FASINEX surface buoy A 
FASINEX Surface Moorings with drifting F10

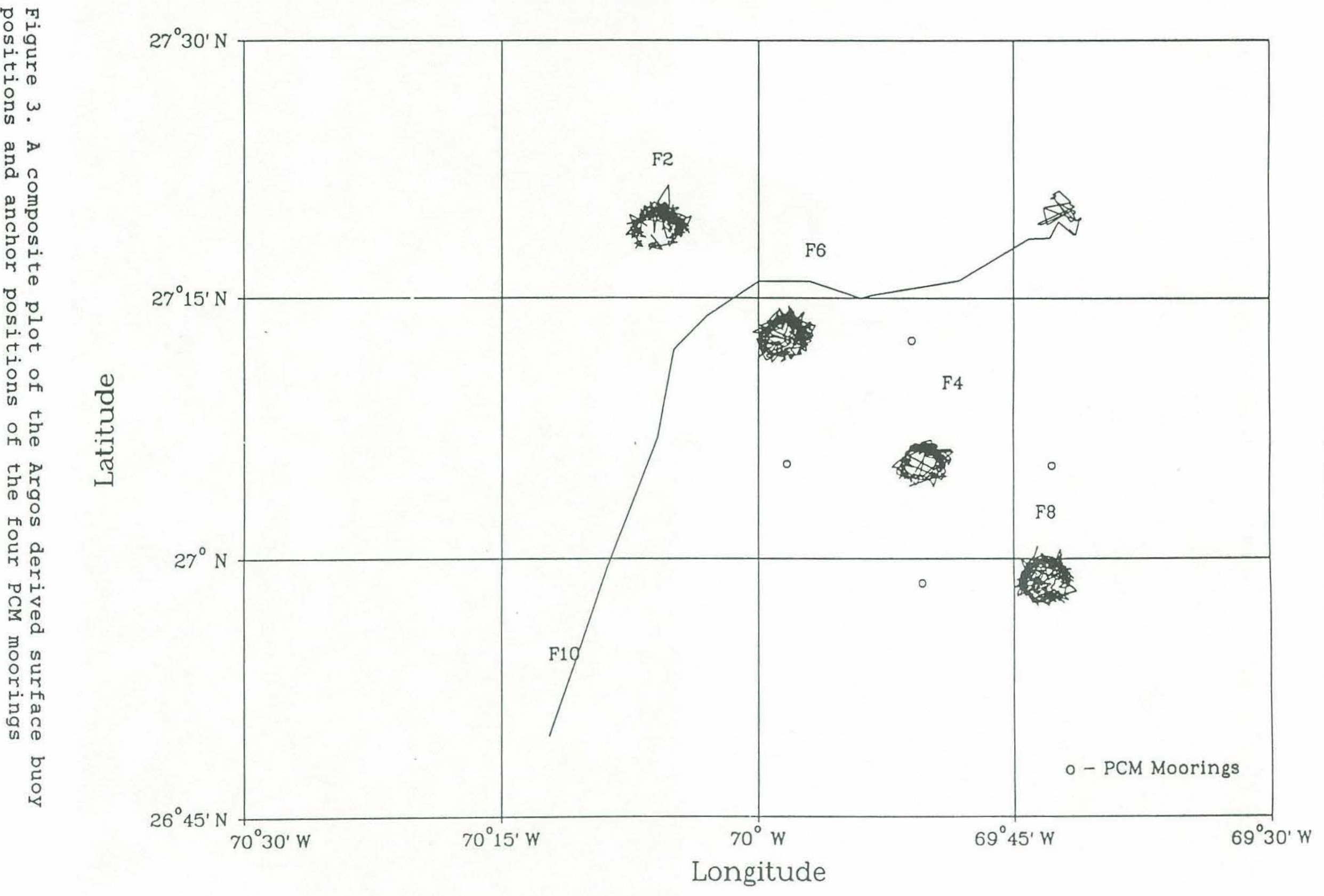


The success of FASINEX relied to a large degree on a satisfactory data return from the Buoy Group's VMCMs since they made up $75 \%$ of the surface mooring current meter array. An investigation was begun into the problems which had appeared during previous deployments and which had prevented the VMCM from working for extended periods (six months) on WHOI surface moorings. Dedicated instrument preparations for FASINEX began nearly one year before the scheduled deployment.

The Buoy Group's inventory of VMCMs consisted of standard EG\&G Sea-Link Model 630 current meters. An analysis of the standard VMCM's performance in high-flow regimes led to a modification to the instrument cage as well as to the support provided for the instrument's propellers. High flow can be attained by subjecting the current meter to large current velocities or by accelerating the instrument through the water as is the case when suspended under a buoy that is actively seeking the trough of a wave. Other VMCM concerns that were addressed and will be discussed include: propeller bearing types, the utilization of external temperature pods for faster response temperature measurements; temperature calibration techniques and results, and cage tests and redesign.

The VACMs used in FASINEX were requested in the early planning stages of the experiment as a backup to the VMCMs which at that time did not have as good a performance record. VACM temperature calibration techniques and data will be compared with nearby (above and below) VMCM calibrated temperature data.

The VAWR with its complement of meteorological sensors was given close attention prior to deployment in order to ensure reliable full-term meteorological measurements. Considerable effort was devoted to the calibration problems before and after the field experiment in order to discriminate between instrumental differences and spatial gradients in the field. A 
discussion of the various sensor types, calibration techniques, and an evaluation of the VAWR data return are presented.

Following recovery of the array, the instrumentation and the data have been carefully examined. In the course of doing so some new procedures were devised for preparing the instrumentation and processing their data. This report will summarize our findings to date in hopes that it will offer assistance to other users of similar instruments. 
II. The VMCM in FASINEX

\section{A. Introduction}

The Vector Measuring Current Meter (VMCM) was developed in the late 1970s by Weller and Davis (1980) in an effort to obtain accurate current measurements in the upper ocean wave zone. The EG\&G Sea Link version of the instrument was first deployed in a four month coastal study (Coastal Ocean Dynamics Experiment, CODE) off California in the summer of 1981. While the sea Link version proved accurate (Beardsley, 1982), several problems came to light, the most serious of which were propeller breakage and sensor bearing failures. The VMCM has undergone a variety of changes since then as additional experience has been gained from subsequent upper ocean experiments using both surface and sub-surface mooring designs.

Another early use of the VMCM was in the Long-Term Upper ocean Study (LOTUS), conducted at $34^{\circ}$ North Latitude and $70^{\circ}$ West Longitude, slightly north of the FASINEX area in the North Atlantic. The current meters were placed in line on a deep ocean surface mooring similar in design to that later used for FASINEX. The LOTUS experiment consisted of several consecutive surface mooring deployments each of approximately 6 months duration. The performance of the VMCMs during the LOTUS deployments was less than satisfactory. The propeller materials were changed from Nory $l^{R}$ to Delrin ${ }^{R}$, and many bearing types of various materials were tried. In addition to premature bearing failure, there were some broken propeller blades, believed to be impact failures attributed to collision with fish, as well as problems with flooded stings (that part of the instrument which supports the propellers and the rotation 
sensing circuit components) and propeller detection

failures. By the end of LOTUS it was clear that more robust bearings were needed, but the cause of the high failure rate of the bearings was not at all clear. More tests were needed. It was felt that the problems experienced during LOTUS were a combined result of the surface wave dynamics in the upper ocean and the rough ride under the discus-shaped surface buoy.

As time went on and the results of other VMCM deployments (both surface and sub-surface) were examined, it became apparent that there were also other problem areas needing attention. FASINEX current meters would probably see much the same conditions as experienced in LOTUS, so an intensive effort to make the design changes necessary to correct the problems was begun in early 1985. There were also modifications to the FASINEX instruments to shorten the thermal time constant of the temperature sensor and refinements to temperature calibrations. In this section we describe the problems and subsequent modifications incorporated in the FASINEX instruments.

\section{B. Propeller Bearings}

The study of early bearing failure quickly branched to include several individual investigations. One area of study that had been underway included a comparison of various bearing materials and bearing types. The objective was to find a bearing design and material which would exhibit an acceptable level of wear in this application at reasonable cost. Another study to examine the external forces on the sting and cage under a dynamic surface buoy and to determine the effect on bearing wear was begun. Each approach is discussed below. 
1. Bearing Material and Design

For the year before the FASINEX deployment, systematic bearing material tests were conducted. Ball bearings and sleeve bearings were evaluated using two test fixtures. The first was a dynamic dockside test that attempted to simulate the vertical accelerations and shock that might be experienced under a discus buoy. The second was an accelerated wear test fixture which permitted comparisons of bearing wear in sea water pumped into the laboratory. Two series of tests were conducted in the dynamic test fixture before it failed and was abandoned. The first series lasted 161 days and the second 45 days. Four series of accelerated wear tests were conducted; these tests overlapped in time depending on when the bearings failed. Materials tested were types 440 and 316 stainless steel, tungsten carbide, silicon nitride, Vespel ${ }^{R}$, and teflon-filled acetal plastic (Delrin ${ }^{R}$ ). Various sizes of bearings (for 1/4-inch, 3/8inch, and 1/2-inch propeller shafts) were used and combinations of materials and assembly techniques were tested. The inner race of some ball bearings was fixed to the shaft with adhesive; different types of ball retainers were evaluated and the effect of sacrificial anodes was tested. The ball bearing and sleeve bearing configurations tested are summarized in Tables II and III. Generally, ball bearings exhibited far superior wear characteristics than the sleeve bearings, and sleeve bearings were dropped as a potential candidate after the first two series of tests. The sleeve bearings tested had three to five times higher threshold, or breakaway torque.

Other considerations given to the choice of bearing included not only the best wear characteristics but also the availability and cost, given the time and budget 
ACCELERATED WEAR TESTS OP VMCM BALL BEARINGS

\begin{tabular}{|c|c|c|c|c|c|c|c|c|c|c|c|c|c|c|c|c|c|c|c|}
\hline & & & & & & & & & & & & $\begin{array}{l}\text { Condition } \\
\text { at end of }\end{array}$ & & $\begin{array}{l}\text { Wear } \\
\text { Upper }\end{array}$ & $\begin{array}{l}\text { ate } 10^{-} \\
\text {Bearing }\end{array}$ & $6 /$ day & $\begin{array}{l}\text { Wear R } \\
\text { Lower }\end{array}$ & $\begin{array}{l}\text { ate } 10^{-} \\
\text {Bearing }\end{array}$ & /day \\
\hline & $\begin{array}{l}\text { rest } \\
\text { No. }\end{array}$ & & & & $\begin{array}{l}\mathrm{Re}- \\
\text { tainer }\end{array}$ & Lab & Armaloy & Shields & $\begin{array}{l}\text { Inner } \\
\text { Race }\end{array}$ & & $\begin{array}{l}\text { Running } \\
\text { Time }\end{array}$ & $\begin{array}{l}\text { test } \\
R=\text { Running }\end{array}$ & $\begin{array}{l}\text { Up/Low } \\
\text { Ball }\end{array}$ & Ball & Inner & Outer & Ball & Inner & Outer \\
\hline ID & & Size & Mat' 1 & Mat'1 & Mat'1 & Impr. & Coated & No. & Glued & Anodes & Days & $P=$ Fafled & $\begin{array}{l}\text { Wear } \\
(.001)\end{array}$ & Wear & Race & Race & Wear & Race & Race \\
\hline 18 & 1 & $1 / 4$ & 316 & 316 & 316 & No & No & 0 & No & No & 6 & $\mathrm{~F}$ & $2.5 / .5$ & 416 & * & - & 83 & - & - \\
\hline in & 1 & $1 / 4$ & 316 & 316 & 316 & No & No & 0 & No & No & 8.6 & 8 & $3.5 / .9$ & 407 & - & * & 105 & - & - \\
\hline IP & 1 & $1 / 4$ & 316 & 316 & 316 & No & No & 0 & No & No & 8.6 & ? & $3.2 / 1.4$ & 372 & : & * & 163 & - & - \\
\hline IY & 1 & $1 / 4$ & 316 & 316 & 316 & No & No & 0 & No & No & 6 & P & $1.6 / 1.0$ & 267 & - & - & 167 & * & * \\
\hline 12 & 2 & $1 / 4$ & 316 & 316 & 316 & No & No & 0 & No & No & 53 & $\mathrm{~F}$ & $5.6 / 1.6$ & 106 & - & * & 30 & - & - \\
\hline 19 & 4 & $1 / 4$ & 316 & 316 & 316 & No & No & 0 & No & No & 30 & $\mathbf{R}$ & $3.0 / .7$ & 100 & 183 & 100 & 23 & 127 & 33 \\
\hline 13 & 1 & $1 / 4$ & 316 & 316 & 316 & No & No & 0 & Yes & No & 64 & $\mathbf{R}$ & $6.6 / 1.6$ & 103 & . & * & 25 & - & - \\
\hline 18 & 2 & $1 / 4$ & 316 & 316 & 316 & No & No & 0 & Yes & No & 75 & R & $2.6 / .6$ & 35 & - & - & 8 & - & - \\
\hline ig & 2 & $1 / 4$ & 316 & $\mathrm{WC} / \mathrm{NI}$ & Delr in & No & No & 0 & Yes & No & 75 & $\mathrm{R}$ & $.1 / .1$ & 1 & - & - & 1 & - & - \\
\hline 16 & 2 & $1 / 4$ & 316 & $\mathrm{Si} / \mathrm{N}$ & Delrin & No & No & 0 & Yes & No & 75 & R & $.2 / .2$ & 3 & - & * & 3 & - & - \\
\hline ID & 1 & $1 / 4$ & 440 & 440 & Phenolic & Yes & No & 1 & No & Yes & 124 & $\mathrm{R}$ & $1.8 / .2$ & 15 & 26 & 36 & 2 & 1 & 3 \\
\hline 14 & 3 & $1 / 4$ & 440 & 440 & Phenolic & Yes & No & 1 & No & Yes & 68 & $\mathrm{R}$ & $2.8 / .2$ & 41 & - & - & 3 & 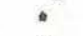 & - \\
\hline 17 & 3 & $1 / 4$ & 440 & 440 & Phenolic & Yes & No & 1 & No & Yes & 68 & $\mathrm{R}$ & $2.1 / .6$ & 31 & * & - & 9 & * & - \\
\hline 17 & 4 & $1 / 4$ & 440 & 440 & Phenolic & Yes & No & 1 & Yes & Yes & 30 & $\mathrm{R}$ & $2.3 / .7$ & 77 & 140 & 183 & 23 & 47 & 33 \\
\hline if & 4 & $1 / 4$ & 440 & 440 & Phenolic & Yes & No & 1 & + & $t$ & 30 & $\mathrm{R}$ & $9 . / 1.1$ & 300 & 190 & 160 & 37 & 53 & 117 \\
\hline 19 & 2 & $1 / 4$ & 440 & 440 & Delrin & No & Yes & 0 & No & Yes & 6 & P & $.9 / .6$ & 150 & - & - & 100 & - & - \\
\hline 15 & 2 & $1 / 4$ & 440 & 440 & Delrin & No & Yes & 0 & No & Yes & 75 & $\mathrm{R}$ & $8.6 / 2.2$ & 115 & * & - & 29 & - & - \\
\hline 11 & 1 & $1 / 4$ & 440 & 440 & Delrin & No & Yes & 0 & Yes & No & 124 & P & $6.21-$ & 50 & - & - & -- & a & - \\
\hline iH & 3 & $1 / 4$ & 440 & 440 & Delrin & No & Yes & 0 & Yes & Yes & 68 & $\mathrm{R}$ & $5 . / 2.6$ & 74 & - & * & 38 & - & - \\
\hline 15 & 4 & $1 / 4$ & 440 & 440 & Minapar & No & No & 2 & Yes : & Yes & 30 & $\mathrm{R}$ & $2.5 / .4$ & 83 & 113 & 100 & 13 & 0 & 0 \\
\hline 10 & 4 & $1 / 4$ & 440 & 440 & Minapar & No & No & 1 & Yes & Yes & 30 & $\mathrm{R}$ & $3 . / .4$ & 100 & 140 & 133 & 13 & 7 & 0 \\
\hline IP & 2 & $1 / 4$ & 440 & $\sin$ & Delrin & No & Yes & 0 & Yes & Yes & 75 & $\mathrm{R}$ & $.8 / .3$ & 11 & - & - & 4 & : & * \\
\hline 10 & 2 & $1 / 4$ & 440 & $\sin$ & Delrin & No & Yes & 0 & Yes & Yes & 75 & $\mathrm{R}$ & $.7 / .3$ & 9 & - & * & 4 & - & • \\
\hline $1 \mathrm{k}$ & 1 & $1 / 4$ & 440 & wc/co & Delrin & No & Yes & 0 & Yes(?) & Yes & 124 & $\mathbf{R}$ & $.7 / 0$ & 6 & - & " & 0 & - & - \\
\hline 10 & 4 & $1 / 4$ & 440 & $w C / N i$ & Minapar & No & No & 1 & Yes & Yes & 30 & $\mathbf{R}$ & $0 / 0$ & 0 & 130 & 0 & 0 & 0 & 0 \\
\hline 14 & 4 & $1 / 4$ & 440 & WC/Co & Phenolic & Yes & No & 1 & Yes & Yes & 30 & $\mathrm{R}$ & $0 / 0$ & 0 & 7 & 17 & 0 & 23 & 0 \\
\hline $\mathrm{IH}$ & 4 & $1 / 4$ & 440 & $\mathrm{WC} / \mathrm{Co}$ & Phenolic & Yes & No & 1 & Yes & Yes & 30 & $\mathrm{R}$ & $0 / 0$ & 0 & 13 & 17 & 0 & 30 & 17 \\
\hline IM & 1 & $3 / 8$ & 316 & wC/co & Delrin & No & No & 0 & Tight & No & 124 & $R$ & $.2 / .2$ & 2 & - & • & 2 & - & - \\
\hline $13 \mathrm{~A}$ & 3 & $3 / 8$ & 440 & 440 & Delrin & No & No & 2 & No & Yes & 64 & $\mathrm{R}$ & $.9 / .7$ & 14 & - & c & 11 & - & - \\
\hline $10 \mathrm{~A}$ & 3 & $3 / 8$ & 440 & 440 & Delrin & No & Yes & 2 & Yes & Yes & 64 & $\mathrm{R}$ & $1.1 / .7$ & 17 & - & - & 11 & - & - \\
\hline IA & 4 & $3 / 8$ & 440 & 440 & Minapar & No & No & 1 & Yes & Yes & 30 & $\mathrm{R}$ & $.4 / .3$ & 13 & 30 & 30 & 10 & 0 & 7 \\
\hline IX & 4 & $3 / 8$ & 440 & 440 & Minapar & No & Yes & 2 & Yes & $\begin{array}{l}t \\
\text { t }\end{array}$ & 30 & $\mathrm{R}$ & $.2 / .2$ & 7 & 17 & 0 & 7 & 7 & 0 \\
\hline 16 & 4 & $3 / 8$ & 440 & 440 & Phenolic & Yes & No & 1 & Yes & Yes & 30 & $\mathrm{R}$ & $.3 / .1$ & 10 & 17 & 27 & 3 & 40 & 0 \\
\hline $\mathrm{IK}$ & 4 & $3 / 8$ & 440 & 440 & Phenolic & Yes & No & 1 & Yes & Yes & 30 & $\mathrm{R}$ & $.4 / .1$ & 13 & 17 & 40 & 3 & 17 & 0 \\
\hline 18 & 4 & $3 / 8$ & 440 & $\mathrm{WC} / \mathrm{Ni}$ & Phenolic & Yes & No & 1 & No & Yes & 30 & $\mathrm{P}$ & $.1 / 0$ & 3 & 1550 & 183 & 0 & 0 & 173 \\
\hline 110 & 4 & $3 / 8$ & 440 & $\mathrm{WC} / \mathrm{Ni}$ & Phenolic & Yes & No & $i$ & No & Yes & 30 & $\mathrm{~F}$ & $.1 / 0$ & 3 & 83 & 683 & 0 & 43 & 1050 \\
\hline IG & 4 & $3 / 8$ & 440 & $\sin$ & Phenolic & Yes & No & 1 & Yes & Yes & 30 & $\mathrm{R}$ & $.1 / .1$ & 3 & 43 & 630 & 3 & 27 & 330 \\
\hline 13 & 4 & $3 / 8$ & 440 & $W C / N i$ & Minipar & No & Ho & 1 & No & Yes & 30 & $\mathrm{R}$ & $0 / 0$ & 0 & 17 & 10 & 0 & 17 & 3 \\
\hline IA & 2 & $3 / 8$ & 440 & $\sin$ & Delrin & No & No & 0 & Tight & Yes & 75 & $\mathrm{R}$ & $0 / 0$ & 0 & . & - & 0 & - & $\cdot$ \\
\hline ic & 2 & $3 / 8$ & 440 & $\mathrm{WC} / \mathrm{Ni}$ & Delrin & No & Yes & 0 & Tight & Yes & 75 & $\mathrm{H}$ & $.2 / .1$ & 3 & - & - & 1.3 & - & - \\
\hline 16 & 1 & $1 / 2$ & 316 & 316 & 316 & No & No & 0 & No & No & 6 & $\mathrm{~F}$ & $2.2 / 1.5$ & 370 & - & - & 250 & - & - \\
\hline
\end{tabular}


Table III

Sleeve Bearings Tested

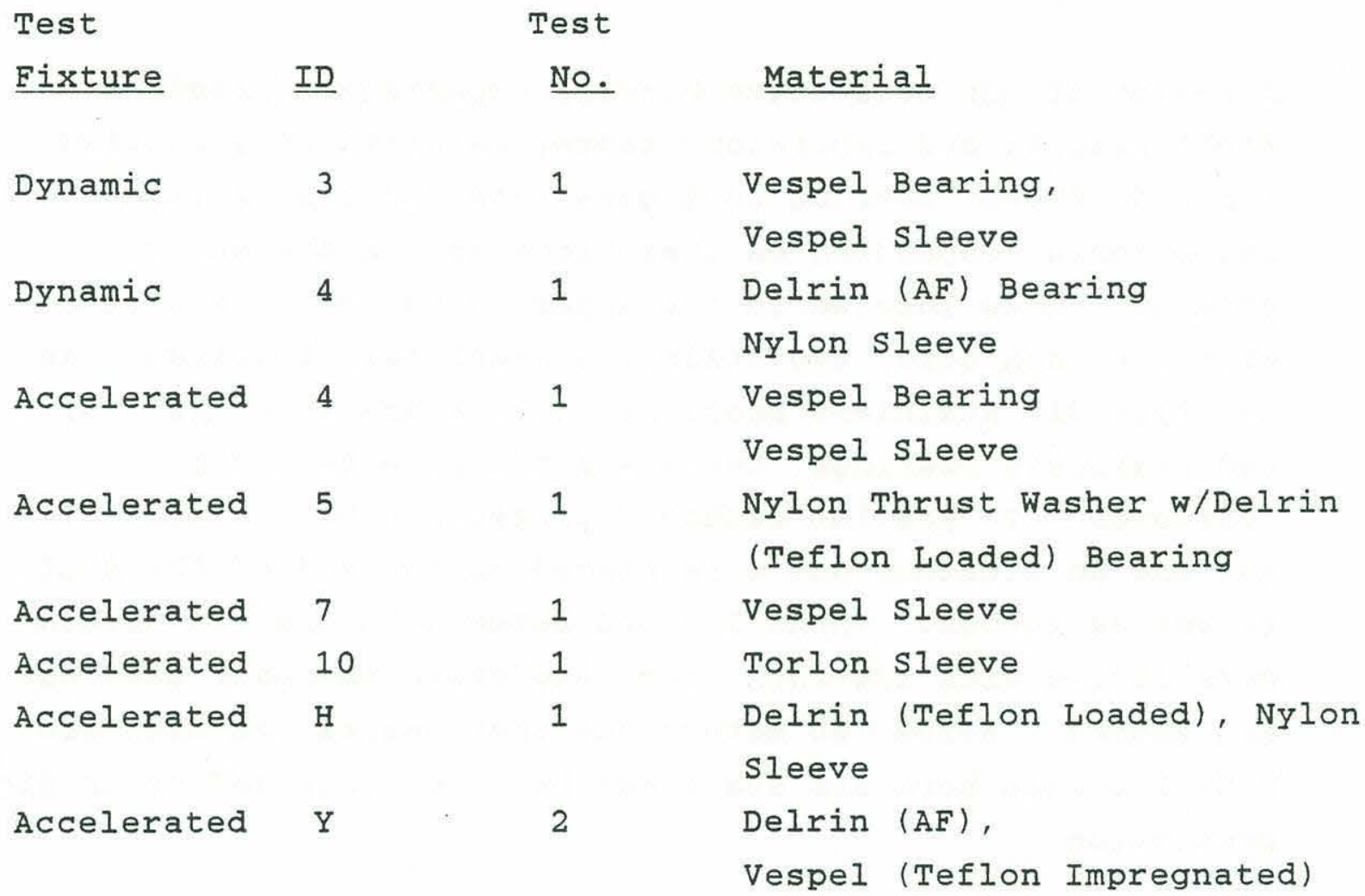


constraints. Materials such as silicon nitride and tungsten carbide were tested as potential for future bearings, but due to their limited availability and high cost, they were not viewed as a viable option for FASINEX. Instead, bearings with which there was some previous field experience and which could be purchased off-the-shelf were thought to be better prospects.

A review of our collective bearing experience (previous field results and laboratory tests) resulted in selecting three different bearing configurations for the FASINEX instruments, depending on their location in the water column. VMCMs located in the upper 70 meters were fitted with $3 / 8$-inch bore, 440 stainless steel ball bearings. As the type 316 stainless propeller shafts are in contact with 440 stainless bearings, there was the potential for corrosion. To provide cathodic protection both a mild steel nut and an aluminum nut were placed on the end of the shaft to act as anodes. VMCMs located between 70 and 700 meters were fitted with $1 / 4$-inch bore 440 stainless ball bearings and anodes. Below 700 meters the instruments had standard VMCM 1/4-inch bore 316 stainless ball bearings and no anodic protection.

The type 440 stainless steel bearings are built with ball retainers made of linen-reinforced phenolic which is vacuum impregnated with lubricating oil. The bearings for the laboratory tests and the field work were made by the Gebrueder Reinfurt Wuerzburg (GRW) Company in West Germany and the New Hampshire Ball Bearing Company (NHBB), of Keene, New Hampshire, a division of Nippon Miniature Bearings, Inc. (NMB). The type 316 stainless steel bearings have a type 316 one-piece pressed stainless steel ball retainers and are made by the Miniature Precision Bearing Company (MPB) of Keene, New Hampshire. 
The axial end play of the propeller shaft was adjusted to between .005" and .007" at room temperature for all bearing configurations. The inner races of bearings for instruments in the upper 700 meters were glued to the propeller shaft using Loctite 271 and Primer T. Following assembly, all instruments were tested in the environmental chamber at $3^{\circ} \mathrm{C}$ and the end-play was measured and recorded. Acceptable bearing break-away torque is qualitatively measured by noting that the propeller comes to rest at regular intervals corresponding to locations of the magnets embedded in a disc mounted on the shaft. This cogging effect is the result of the attraction between the magnets and the Sony magnetodiode rotation sensor, and shows that the bearing break-away torque (threshold) is smaller than the diode-to-magnet attraction. As a final check it was verified that the propeller shafts would $\operatorname{cog}$ at both $3^{\circ} \mathrm{C}$ and at room temperature,

To gain further field experience with bearing types, VMCM bearing test cages were deployed at 50 meters depth on three of the FASINEX moorings. Each test cage has four VMCM type propeller assemblies without any electronics. The various configurations of bearings that were tested are described below. Unless otherwise noted, the bearings were size SR6, with $0.875(7 / 8)$ inch Outside Diameter (O.D.) and 0.375 $(3 / 8)$ inch bore; these are called 3/8-inch bearings. The other bearings used are called 1/4-inch bearings; these are size SR4 and have a $0.625(5 / 8)$ inch O.D. and a $0.250(1 / 4)$ inch bore. 
Test cage 1 , mooring 845 , FASINEX mooring $F 2$

Upper hub: silicon nitride balls and races with Minipar II retainer.

Second hub: tungsten carbide balls and races with Minipar II retainer.

Third hub: tungsten carbide balls with type 440 stainless steel races.

Lower hub: type 440 stainless steel balls and races with phenolic retainer.

Test cage 2, mooring 849 , FASINEX mooring F10

Configured the same as test cage 1 except for $1 / 4$-inch bearings of the same materials on the third hub.

Test cage 3 , mooring 847 , FASINEX mooring $F 6$

Upper hub: Silicon Nitride balls and races; separable bearing. There was no ball retainer.

Second hub: Tungsten Carbide balls and races, 1/4-inch size, phenolic retainer.

Third hub: Tungsten Carbide balls, stainless steel races; 1/4-inch size, phenolic retainer.

Lower hub: Grade 440 stainless steel balls and races, a standard off-the-shelf bearing with phenolic retainer. 
All of the 1/4-inch bearings at 50 meters depth failed. Considerable wear was observed in the 3/8-inch bearings with grade 440 stainless steel balls and races. The bearings with silicon nitride balls and races showed the least wear and minimal degradation in performance. The others were generally in good condition with detectable increases in friction and roughness over unused bearings.

\section{Cage Redesign}

In an attempt to understand the problem of premature bearing failures, the response of the VMCM sting and cage was examined in a flow environment. To evaluate the sting response to flow stimulus, a test was devised to measure the acceleration and displacement of the sting and cage assembly under steady state conditions. A VMCM was suspended below the $\underline{R / V}$ Asterias with a 1500 pound depresser weight and towed at various speeds (Figure 4.) Vibration amplitudes and periods from strategically placed accelerometers mounted on the instrument sting and cage were recorded from each of several trials. A standard VMCM cage constructed of 1/2inch diameter rods was fitted with several configurations of sting supports and tested. A cage with 3/4-inch diameter rods was constructed and similarly tested. The results of the tests are summarized in Table IV.

Table IV shows that a significant decrease in acceleration and displacement is realized by replacing the 1/2-inch members in the cage with the 3/4-inch material and adding a cross brace between the propellers to support the sting. Since maximum sting and cage accelerations were expected near the surface in response to orbital wave velocities and relatively higher current flow, cages constructed with 3/4inch diameter rods were used on the upper three VMCMs on each mooring. The remaining VMCMs were fitted with standard 


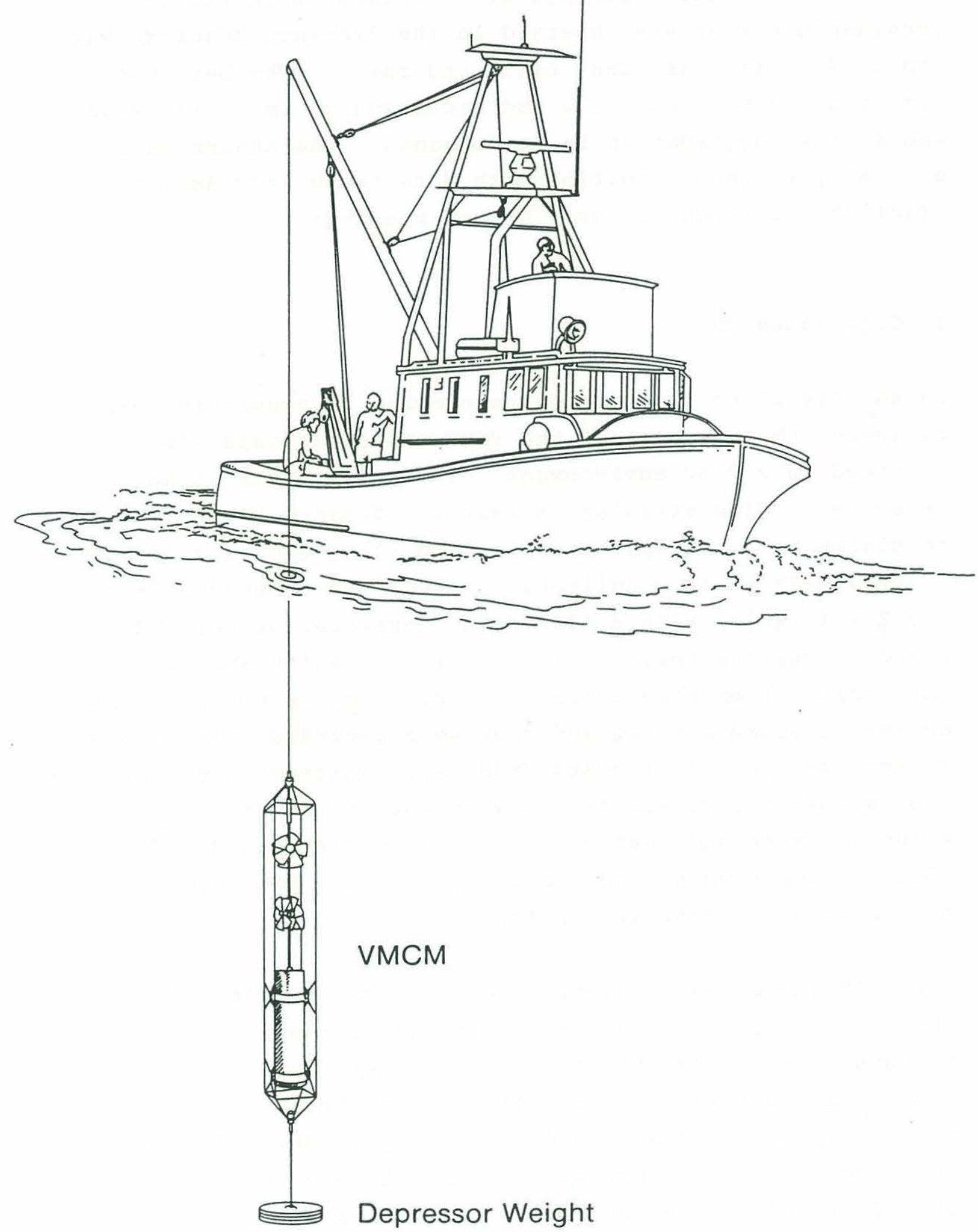

Figure 4. VMCM sting and cage tow test 
Table IV

VMCM Sting Acceleration and Displacement at 6 Knots $(300 \mathrm{c} / \mathrm{s})$

\begin{tabular}{|c|c|c|}
\hline CONFIGURATION & Acceleration (G) & Displacement (inches) \\
\hline & . & \\
\hline Standard $1 / 2 "$ rod cage & 2.60 & 0.036 \\
\hline Standard $1 / 2 "$ rod cage & 1.36 & 0.010 \\
\hline with maximum truss & & \\
\hline $3 / 4 "$ cage with 1 cross & 0.86 & 0.006 \\
\hline
\end{tabular}


VMCM cages constructed of 1/2-inch cage rods. All cages had a single cross brace to support the sting between the two sets of propellers. Tow tank tests showed that the addition of the cross brace did not significantly affect the steady response characteristics of the sensor.

\section{Bearing Performance}

The FASINEX VMCMs were in good condition at the time of their recovery after 150 days at sea. Immediately following the recovery, bearing end-play was measured and a qualitative propeller bearing friction test measuring the length of time for the propeller to stop turning after being spun was also conducted. An average of three readings each with the shaft vertical and horizontal was used as the spindown value.

Average wear rate for the three bearing types used on the FASINEX VMCMs has been computed by comparing the end-play before and after the field experiment. The $3 / 8$-inch bore 440 stainless steel bearings showed an average increase in end-play of 0.001 inch after 150 days at sea. The 1/4-inch bore bearings of 440 stainless steel exhibited an increase of 0.003 inch after 150 days, and the 1/4-inch bore bearings of 316 stainless steel showed an average increase in axial end-play of 0.007 inch.

The relative bearing wear observed during FASINEX was analogous to that seen in the accelerated wear tests. During the final round of accelerated wear tests, the 3/8inch bore bearings of 440 stainless steel wore an average of 0.005 inch in thirty days, the $1 / 4$-inch bore 440 stainless bearings showed an increase in end-play of 0.017 inch in thirty days, and the 316 stainless steel bearings with 1/4inch bore had an average increase in axial end-play of .025 
inch. It should be noted when comparing wear rates from FASINEX, that the mean current flow in the upper water where the 440 stainless steel bearings were placed averaged 19 to $25 \mathrm{~cm} / \mathrm{s}$ with bursts of up to about $95 \mathrm{~cm} / \mathrm{s}$ which lasted for as long as a week. Deeper, the flow was 4 to $9 \mathrm{~cm} / \mathrm{s}$ in the region where instruments with 316 stainless steel bearings were placed. The accelerated wear test machine ran the bearings at speeds equivalent to a current of about 11 knots, or over $550 \mathrm{~cm} / \mathrm{s}$.

Placing 440 stainless bearings on type 316 stainless shafts and protecting the dissimilar metal against galvanic corrosion with anodes seemed to work well. Corrosion was minimal; however, the combination of the different materials created an electrical potential which caused Aragonite to precipitate out of the water and to be deposited in the bearings and on the shaft assembly (Dexter, et. al. 1975). This carbonate precipitate was found present in the hub assemblies which contained the dissimilar metals; the 316 stainless bearings on 316 stainless shafts and the nonmetalic synthetic bearings under test showed no deposition. Overall, the Aragonite precipitate did not appear to have much effect on the spin-down time of the $3 / 8$-inch bore 440 bearings. On the other hand, the post-cruise spin-down performance of the 1/4-inch 440 stainless steel bearings was somewhat impaired by the precipitate. The incidence of the deposit increased with depth, presumably due to the reduced flushing of water in the bearing and shaft housing of the smaller bearing in the low current regime. Further testing is being done to try to eliminate formation of the precipitate. A design which utilizes 440 stainless steel for bearings and propeller shaft was tested in the lab test fixture and in a later (1987-88) one-year sea test at Site L $\left(34^{\circ} \mathrm{N}, 70^{\circ} \mathrm{W}\right)$ in efforts to reduce or to eliminate the need for anodic protection. The tests showed corrosion to be excessive without the anodes, and in fact, several 440 
stainless steel shafts broke during the one year tests, a failure mode not yet experienced with the less strong but more corrosive resistant grade 316 steel.

\section{Flooded stings}

In previous deployments the Buoy Group had observed several occurrences of flooded sensor supporting stings, a problem which appeared to be caused by a low pressure leak in the sting. Studies revealed that an accumulation of tolerances (tolerance build-up) in the machined components could result in a condition of zero compression of the o-ring seal. Redesigned parts were made for FASINEX to eliminate the excessive clearance. The sting was also modified so that a vacuum could be drawn in the sting to test the seal and to provide insurance against low pressure leaks.

\section{Propeller Detection Failures}

The propeller sensing components in the FASINEX VMCMs are magneto-diodes, semi-conductor components which sense the motion of magnets mounted on the propeller shaft. The diodes are mounted on a small circular circuit board which is installed in the propeller hub of the VMCM sting. The original board design allowed circuit wiring to be in contact with the aluminum hub material. The problem was not evident early in the VMCM life because the anodizing treatment on the hub forms an electrical insulating surface. However, in time the surface insulating layer began to break down from repeated use, and rotor detection failures occurred. The solution was to re-design the diode circuit boards and eliminate the contact. New circuit boards for the VMCMs were provided by EG\&G in exchange for the old boards (EG\&G Service Bulletin 11-6). 


\section{E. Temperature Sensor Time Constant}

The VMCM temperature sensor, a thermistor, is mounted to the upper pressure housing plate. The response of the sensor to changes in water temperature is therefore rather slow. The (1 - 1/e) time constant (the length of time for the sensor to respond to $63 \%$ of a step input temperature change) for the standard VMCM is about 80 seconds. It is desirable to have the time constant shorter than the sampling period. To shorten the time constant, the sensor was installed in an external pod with greatly reduced thermal mass. Figure 5 is a section view of the fast response pod and its relationship to the standard chassis mounting, and Figure 6 shows the results of actual response tests for both configurations. The $(1-1 / e)$ time constant for the added pod was measured to be about ten seconds.

\section{F. Calibrations and Corrections to the Temperature Data}

Post-cruise VMCM temperature calibrations and comparisons with the VACM in the vertical array of each mooring highlighted a systematic error in the VMCM temperature measurements. Analysis of the temperature circuits in the VMCM and a review of the Buoy Group thermistor calibration procedures revealed the problem. The same thermistor type is used in the VMCM and some VACMs. To eliminate selfheating error in the VACM temperature data, the sensors are individually calibrated at a power level corresponding to about $10 \mathrm{~m}^{\circ} \mathrm{C}$ of self-heating. However, the VMCM circuitry is different and self-heating is not a factor; a $10.1 \mathrm{~m}^{\circ} \mathrm{C}$ bias (see Appendix) has been added to the VMCM temperature data to compensate. Constant-temperature bath calibrations were done and with the self-heating bias correction the VMCM 


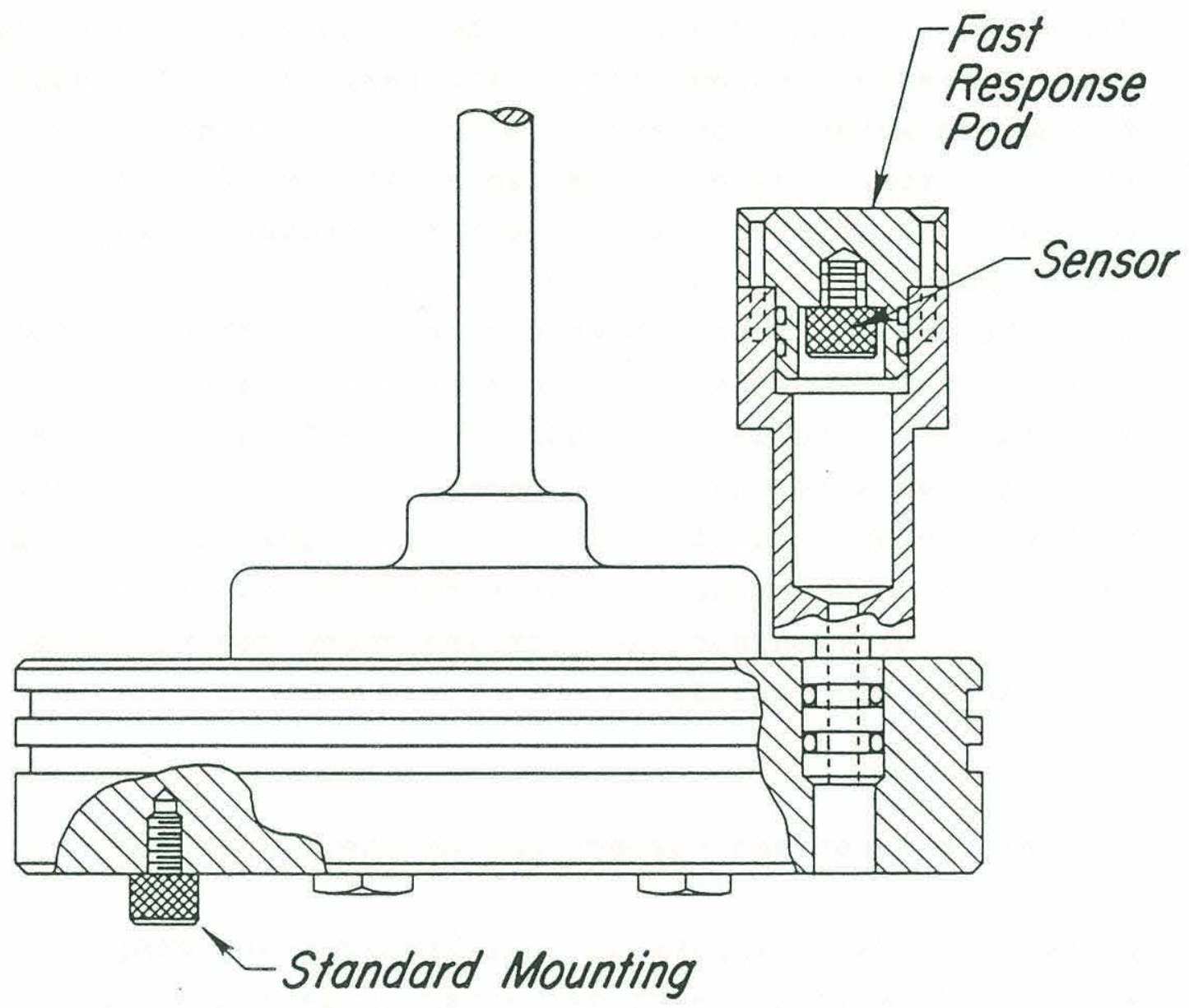

Figure 5. Section view of the VMCM end plate with a standard temperature sensor and a fast response pod 


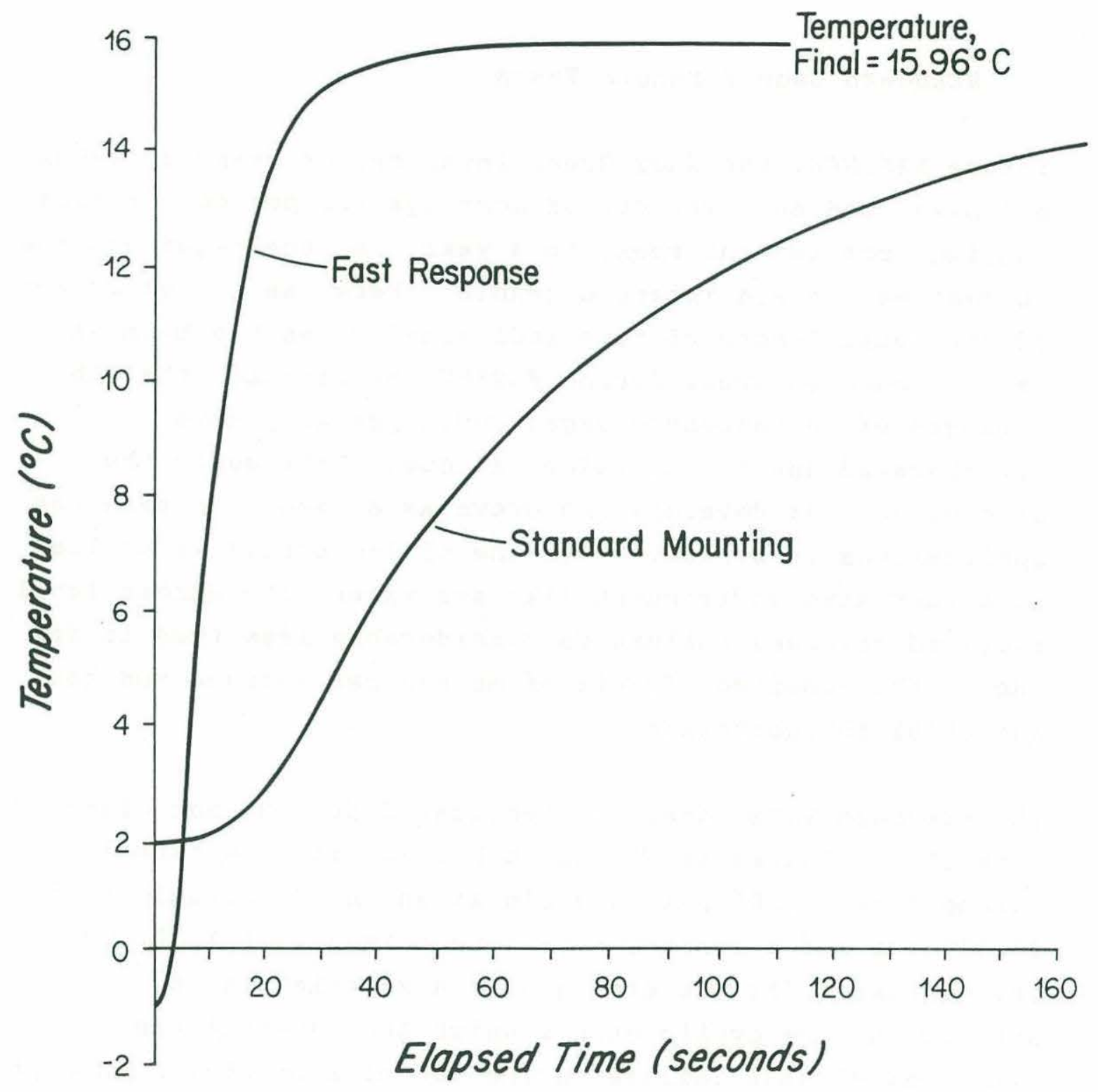

Figure 6. Temperature sensor time constant response curves 
data all agree with the lab standard measurement within $0.010^{\circ} \mathrm{C}$, and all except one within $0.007^{\circ} \mathrm{C}$. Analysis of the sea data at a time chosen when the upper 80 meters in the ocean was well mixed shows that the VMCM temperatures compare well with the VACM temperature measurements.

\section{G. Standard Cage Strength Tests}

Before FASINEX, the Buoy Group inventory of standard VMCMs had been used on a variety of moorings for periods of time ranging from several weeks to a year. As the cages and the current meters are interchangeable, there was no record kept of the total length of time individual cages had been at sea. A concern arose during FASINEX preparation that the strength of the standard cages could possibly have deteriorated due to corrosion fatigue. Fatigue is the fracturing that develops and grows as a result of repeated applications of stress. When the cyclic stress is applied in a corrosive environment like sea water, the stress level required to cause failure is considerably less than in air due to the combined effects of mechanical fatigue and the potential for corrosion.

The standard VMCM cages are fabricated of 1/2-inch diameter type 316 stainless steel, which has an ultimate tensile strength of 80,000 psi, a yield strength of approximately $30,000 \mathrm{psi}$ and a corrosion fatigue strength of $14,000 \mathrm{psi}$. The corrosion fatigue strength of a material is, by definition, the cyclic stress which the material can withstand without failure during 100 million cycles (MC) of stress (LaQue, 1975.) It is estimated that cages deployed in line on an active surface mooring are stressed about one Mc in six months! As there was no record of the condition of the cages, they were carefully inspected with the guidance of a metallurgical consultant. 
The cages were first inspected visually for cracks and then with the aid of a dye which flows into the crack to facilitate visual inspection. No evidence of corrosion or cracking was observed. The cages were also checked using an audio comparison technique; the theory being that, when struck by a mallet, cracked components will not ring as clearly and sharply as uncracked components. Areas that showed some slight dissonance were again tested using dye. Two cages that had the most dissonance were loaded in tension with the dye applied. No cracks were detected in either case.

As a test for strength one cage was pulled to destruction. It was instrumented to measure elongation at three points along the cage as well as to measure the overall elongation observed as it was loaded. The highest load achieved was 27,600 pounds. The upper cross piece of the cage buckled while the lower cross pieces were only slightly deflected due to the support provided by the instrument case and its associated brackets. Measurements made along the strength rods after failure indicated that there was no permanent elongation, implying that yield of the material had not occurred. The cage structure failed before the material deformed. The stress in each rod was calculated to be $48,797 \mathrm{psi}$ without any indication of yield. This is approximately 50\% greater than the yield strength typically specified for type 316 stainless steel. No welds failed.

The conclusion drawn from this series of tests was that corrosion fatigue was not a problem with the present inventory of VMCM cages. It was recommended, however, that future use be logged along with an estimate of the loads experienced. Future cage inspections will include visual checks, the use of dye in questionable areas, and a check for audio dissonance when struck by a mallet. The cages 
will be anodically protected as further insurance against corrosion, and provision for an anode was made at the top of the cage to supplement the standard anode placed at the bottom. 
III. The VAWR in FASINEX

\section{A. Introduction}

To better understand the interaction and energy exchange between the atmosphere and the ocean and to study the atmospheric mechanisms that drive the upper ocean, one must gather meteorological data near the ocean surface. The Vector Averaging Current Meter (VACM) has been used for many years as a long-term reliable meter to provide a continuous record of ocean current velocities and to serve as a data recording instrument for temperature and other variables. Its vector-averaging capabilities and its record as a reliable data logger made it a natural choice for conversion to a meteorological recorder. Investigators first successfully converted the VACM into a Vector Averaging Wind Recorder (VAWR) for field experiments conducted in the early 1970 's (Payne 1974).

The present WHOI Integral VAWR with Gill three-cup anemometer was first deployed in the second small-scale Coastal Ocean Dynamics Experiment (CODE-2) in 1982. Dean and Beardsley (1988) describe the Integral VAWR design that puts the anemometer atop a three-legged support that also serves as a protective cage for the wind vane. The vane mounts directly below the cups inside the cage and is magnetically coupled to a VACM vane follower, a seven-bit digital encoder located inside the cylindrical electronics housing (Figure 7). This design provides an integral assembly requiring no special alignment of vane and compass when the VAWR is placed on the buoy tower. VAWRs are instrumented to measure and record east and north wind velocity components, air and seawater temperature', incident solar radiation, barometric pressure, and relative humidity (with difficulty). 


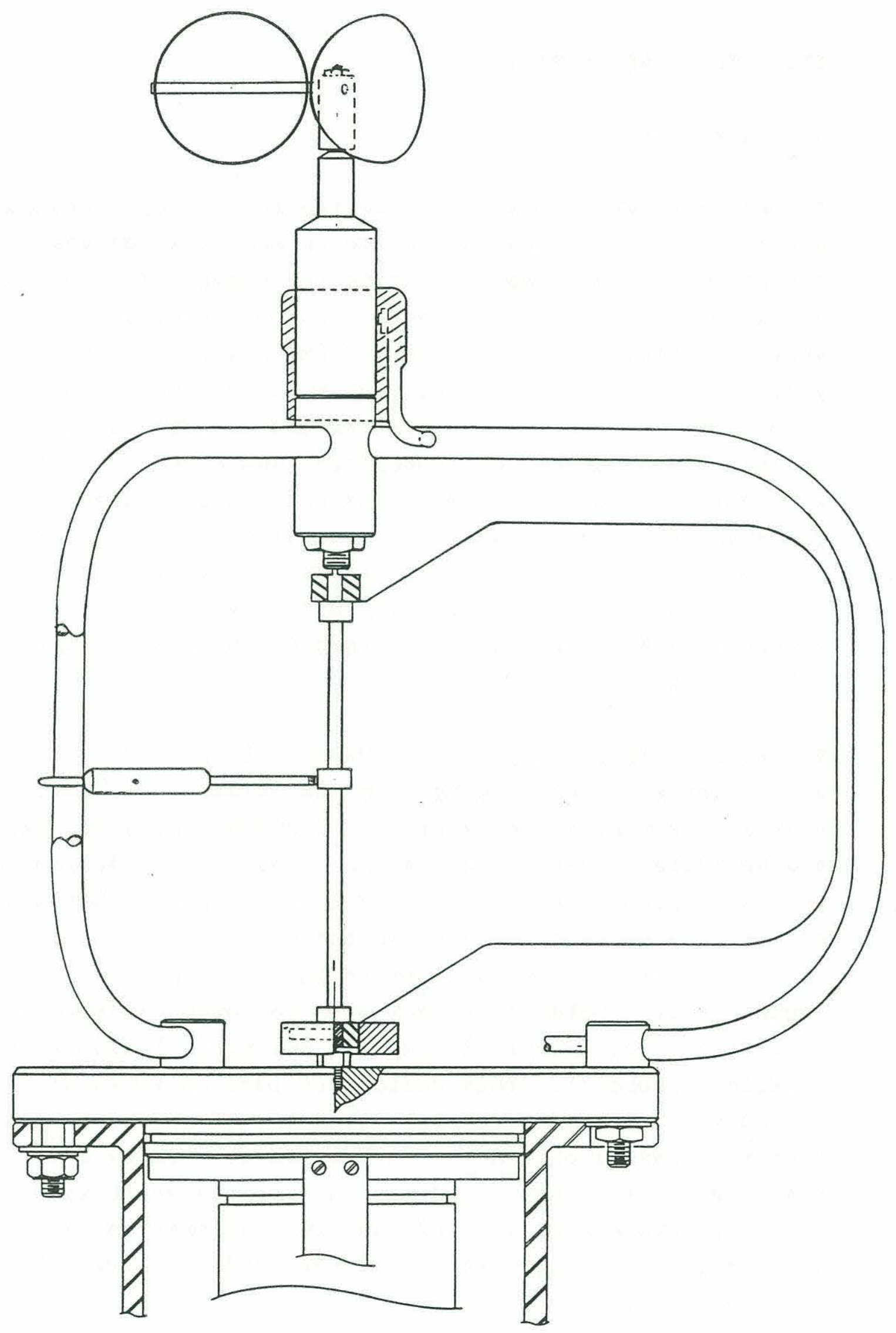

Figure 7. VAWR wind speed and direction sensors 
Two meteorological packages, the Integral VAWR described above and a Meteorological Recorder (MR) developed at WHOI by $R$. Payne (Payne, 1988), were deployed on each FASINEX buoy. The Integral VAWR (hereafter simply called the VAWR) was the responsibility of the Buoy Group, and R. Payne was responsible for the MR. A specification summary for the VAWR sensors used in FASINEX appears in Table V. The positions of the VAWR and MR sensors on the surface buoy are shown in Figure 8, and the sensor height above the water is summarized in Table VI. A discussion on each of the individual VAWR sensors follows.

B. Wind Speed, Direction and Velocity

The VAWR anemometer is an aluminum, three-cup hemispherical rotor manufactured by the R.M. Young Co. A magnetic disc is attached to the rotor via a central steel shaft and produces two pole reversals with each rotation of the shaft. A magneto-diode senses each half rotation of the anemometer and initiates a compute cycle in the VAWR. A vector computer calculates and stores east and north wind component displacement past the rotor. The average of these vector components over a pre-set interval and the total rotations are permanently stored on magnetic tape.

Specifications for the anemometer are:

$\begin{array}{ll}\text { Range } & 0.2 \text { to } 50 \mathrm{~m} / \mathrm{s} \\ \text { Accuracy } & \pm 2 \% \text { above } 0.2 \mathrm{~m} / \mathrm{s} \\ \text { Threshold } & 0.2 \mathrm{~m} / \mathrm{s} \\ \text { Resolution } & 0.375 \mathrm{~m} \pm 2 \% \text { of wind run } \\ \text { Distance constant } & 3.7 \mathrm{~m}\end{array}$


Summary of Meteorological Sensor Specifications

VAWR (Vector Averaging Wind Recorder) (450 second recording rate)

\begin{tabular}{|c|c|c|c|c|}
\hline Parameter & Sensor & Range & $\begin{array}{l}\text { Height } \\
\text { (cm) }\end{array}$ & Comments \\
\hline Wind Speed & $\begin{array}{l}\text { Gill 3-cup } \\
\text { Anemometer } \\
\text { R.M.Young } \\
\text { Model } 6301\end{array}$ & $0.2-50 \mathrm{~m} / \mathrm{s}$ & 356 & $\begin{array}{l}\text { Vector- } \\
\text { averaging }\end{array}$ \\
\hline $\begin{array}{l}\text { Wind } \\
\text { Direction }\end{array}$ & $\begin{array}{l}\text { Integral vane } \\
\text { w/vane follower } \\
\text { WHOI/EG\&G }\end{array}$ & $0-360^{\circ}$ & 327 & $\begin{array}{l}\text { Vector- } \\
\text { averaging }\end{array}$ \\
\hline Insolation & $\begin{array}{l}\text { Pyranometer } \\
\text { Eppley } \\
\text { Model } 8-48\end{array}$ & $\begin{array}{l}0-150 \underline{0}_{2} \\
\text { watts }-\mathrm{m}\end{array}$ & 352 & $\begin{array}{l}\text { Average } \\
\text { system }\end{array}$ \\
\hline $\begin{array}{l}\text { Relative } \\
\text { Humidity }\end{array}$ & $\begin{array}{l}\text { Variable } \\
\text { Dielectric } \\
\text { Conductor } \\
\text { Vaisala } \\
\text { Humicap } 1518 \mathrm{HM}\end{array}$ & $0-100 \%$ & 294 & $\begin{array}{l}3.5 \mathrm{sec} \\
\text { sample }\end{array}$ \\
\hline $\begin{array}{l}\text { Barometric } \\
\text { Pressure }\end{array}$ & $\begin{array}{l}\text { Quartz crystal } \\
\text { Digiquartz } \\
\text { Paroscientific } \\
\text { Model 215-AS (AW) }\end{array}$ & $0-1034 \mathrm{mb}$ & 218 & $\begin{array}{l}2.5 \mathrm{sec} \\
\text { sample } \\
\text { Note } 1\end{array}$ \\
\hline $\begin{array}{l}\text { Temperature } \\
\text { (Sea) }\end{array}$ & $\begin{array}{l}\text { Thermistor } \\
\text { Thermometrics } \\
4 \mathrm{~K} @ 25^{\mathrm{C}} \mathrm{C}\end{array}$ & $-5-+30^{\circ} \mathrm{C}$ & -68 & $\begin{array}{l}1 / 2 \text { time } \\
\text { average } \\
\text { Note } 2 .\end{array}$ \\
\hline $\begin{array}{c}\text { Temperature } \\
\text { (Air) }\end{array}$ & $\begin{array}{l}\text { Thermistor } \\
\text { Yellow springs } \\
\# 44034 \\
5 \mathrm{~K} \text { @ } 25^{\circ} \mathrm{C}\end{array}$ & $-10-+35^{\circ} \mathrm{C}$ & 259 & $\begin{array}{l}1 / 2 \text { time } \\
\text { average } \\
\text { Note } 3 .\end{array}$ \\
\hline
\end{tabular}

Notes:

1. Burst samples are taken at halfway point of averaging (recording) interval.

2. Sea temperature is measured during the first half of recording interval.

3. Air temperature is measured during the second half of the recording interval. 


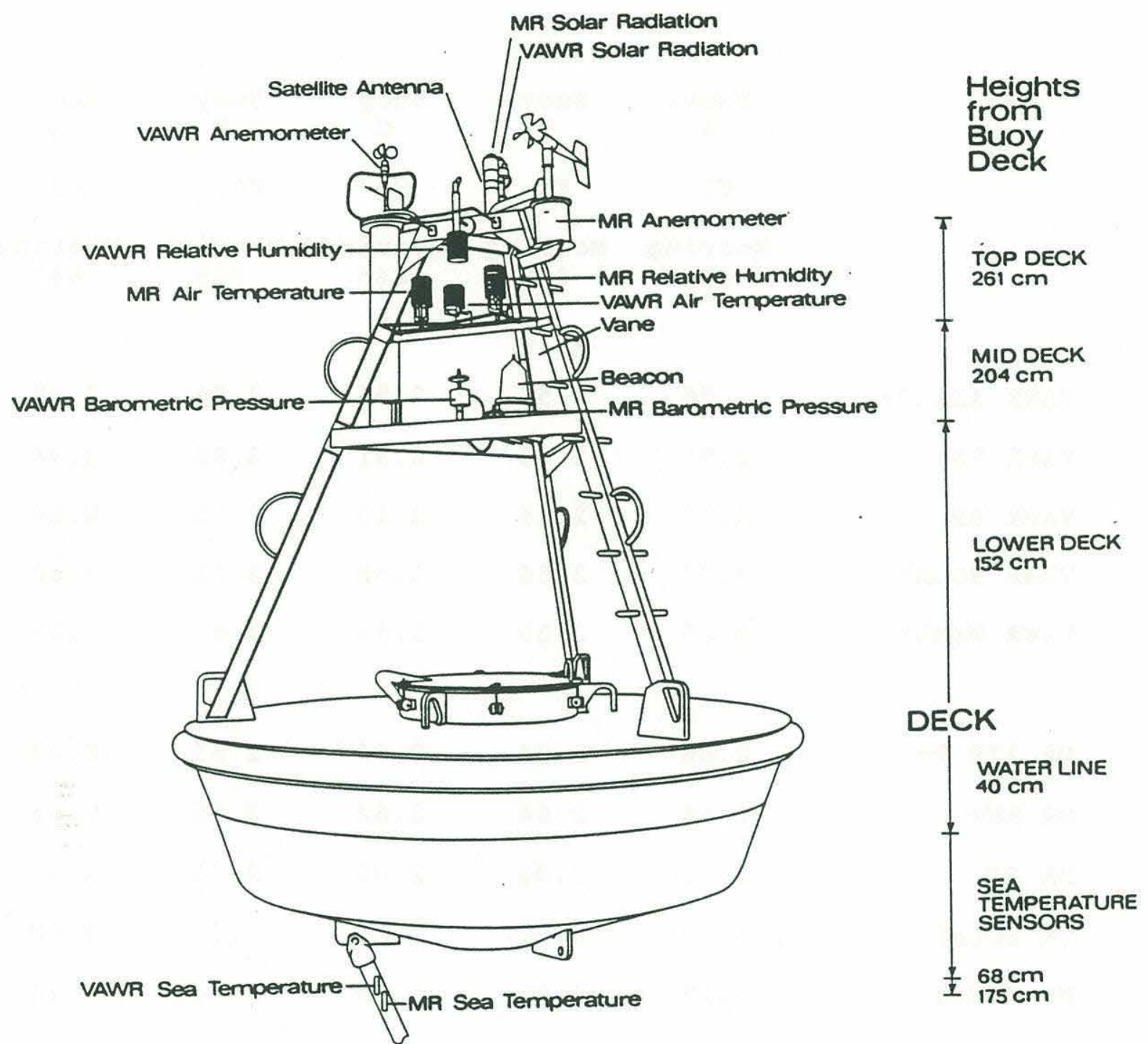

Figure 8. FASINEX surface buoy with meteorological instrumentation 
Table VI

Meteorological Sensor Heights Above the Buoy Waterline

$\begin{array}{ccccc}\begin{array}{c}\text { Buoy } \\ \text { A }\end{array} & \begin{array}{c}\text { Buoy } \\ \text { B }\end{array} & \begin{array}{c}\text { Buoy } \\ \text { C }\end{array} & \begin{array}{c}\text { Buoy } \\ \text { D }\end{array} & \begin{array}{c}\text { Buoy } \\ \text { E }\end{array} \\ \text { F2 } & \text { F6 } & \text { F4 } & \text { F10 } & \text { F8 } \\ \begin{array}{c}\text { Mooring } \\ 845\end{array} & \begin{array}{c}\text { Mooring } \\ 847\end{array} & \begin{array}{c}\text { Mooring } \\ 846\end{array} & \begin{array}{c}\text { Mooring } \\ 849\end{array} & \begin{array}{c}\text { Mooring } \\ 848\end{array}\end{array}$

$\begin{array}{llllll}\text { VAWR AIR T+ } & 2.56 & 2.57 & 2.56 & 2.56 & 2.58 \\ \text { VAWR RH+ } & 2.91 & 2.93 & 2.91 & 2.86 & 2.96 \\ \text { VAWR BP } & 2.17 & 2.15 & 2.13 & 2.15 & 2.16 \\ \text { VAWR SOLAR } & 3.56 & 3.56 & 3.55 & 3.51 & 3.60 \\ \text { VAWR WIND* } & 3.55 & 3.55 & 3.54 & 3.50 & 3.59 \\ & 2.66 & 2.64 & 2.63 & 2.65 & 2.67 \\ \text { MR AIR. T+ } & 2.66 & 2.64 & 2.64 & 2.65 & 2.66 \\ \text { MR RH+ } & 2.00 & 2.02 & 2.00 & 2.01 & 2.02 \\ \text { MR BP } & 3.56 & 3.56 & 3.55 & 3.51 & 3.60 \\ \text { MR SOLAR } & 3.39 & 3.39 & 3.39 & 3.34 & 3.44 \\ \text { MR WINDS } & & & & & \end{array}$

* Measurement to the centerline of cups

+Measurement to the mid-point of the shield

Units = Meters above the waterline (waterline location = $0.40 \mathrm{~m}$ below deck) 
The VAWR wind vane is magnetically coupled to a vanefollower installed inside the cylindrical electronics housing. The position of the vane relative to the buoy is measured each half revolution of the anemometer. The vanefollower digital output signal is combined with the compass heading in calculating the vector components of the wind velocity. The compass is installed inside the lower part of the housing as part of the chassis assembly and aligned to the vane-follower as an integral unit.

Specifications for the compass, vane and vane-follower are tabulated below.

$\begin{array}{ll}\text { Range } & 0-360^{\circ} \\ \text { Accuracy } & \\ \text { Vane linearity } & 2 \text { bits }\left(5.6^{\circ}\right) \\ \text { Vane alignment } & 1 \text { bit }\left(2.8^{\circ}\right) \\ \text { Compass linearity } & 2 \text { bits } \\ \text { Compass alignment } & 1 \text { bit }\end{array}$

Total possible direction error $=6$ bits $\left(16.9^{\circ}\right)$, $\operatorname{RMS}=7.4^{\circ}$

Resolution $\quad$ I bit $\left(2.8^{\circ}\right)$

Compass time constant 10 seconds

Vane-follower time constant 1 second

Vane delay distance 0.75 meters

The delay distance of the vane was calculated using the technique described by McCready and Rex (1964); it is defined as the length of a run of wind required to cause the vane to fully respond to a change in wind direction of $10^{\circ}$. The eddy-current damping in the vane-follower, a one to three second time delay (time constant), tends to filter or 
smooth the high frequency flutter characteristic of the short vane. The rotor and vane sensors are attached to the assembly housing and mounted on the buoy tower, 3.5 meters above the mean water line.

Direction accuracy as specified is the total of compass and vane errors for the VAWR. Vector-averaged direction errors usually are statistically much less; in certain cases direction error (accuracy) is influenced by sensor characteristics, such as the anemometer and vane threshold. Basically, the VAWR is a VACM, except that the platform motion may introduce direction errors which must not be ignored in a system error analysis. For example, the VAWR compass has a ten-second time constant, meaning that the compass requires ten seconds to respond to a step input. Under some conditions on an active buoy with non-symmetric yaw motion, the direction errors may be quite large. These dynamic errors have not been measured and are not discussed further here. Static system direction tests were done.

\section{Direction Comparison Tests}

Before and after the experiment, the five FASINEX buoys were placed on a test station that could be rotated. As each buoy was turned through $360^{\circ}$, the wind vane was directed to a fixed target at $60^{\circ}$ intervals. The direction was computed from the VAWR compass and vane-follower data; results are given in Table VII.

The test site was the northeast corner of the WHOI courtyard surrounded by the Bigelow, Smith, and Iselin buildings and the wHOI dock. This site showed little horizontal or vertical spatial variation in the magnetic field. Compass measurement of the magnetic headings of various landmarks to the northwest agree with the bearings taken from navigation 


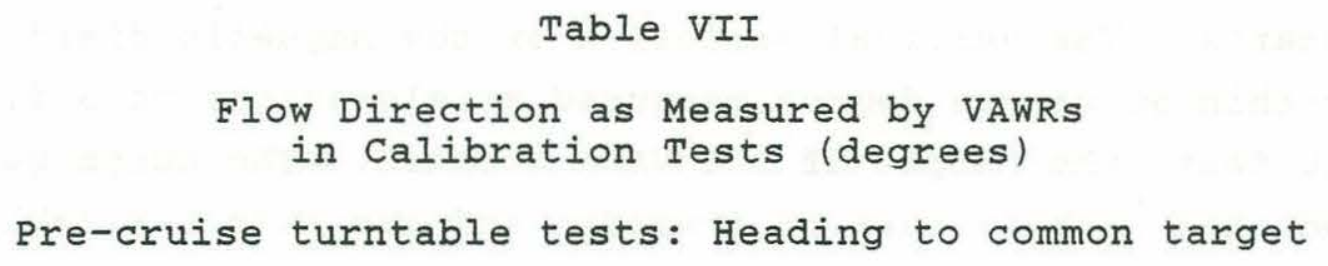

\begin{tabular}{|c|c|c|c|c|c|c|}
\hline BUOY & & $\begin{array}{l}\text { A } \\
143 . \\
146 . \\
140 . \\
146 . \\
140 . \\
140 . \\
146 .\end{array}$ & $\begin{array}{c}\text { B } \\
138 \\
141 \\
144 \\
144 \\
144 \\
144 \\
141\end{array}$ & $\begin{array}{c}C \\
141 . \\
146 \\
144 \\
143 \\
141 \\
138 \\
144\end{array}$ & $\begin{array}{l}D \\
146 \\
143 \\
144 \\
146 \\
146 \\
141 \\
138\end{array}$ & $\begin{array}{c}E \\
143 . \\
147 \\
144 \\
144 \\
147 \\
143 \\
146\end{array}$ \\
\hline \multirow[t]{2}{*}{$\begin{array}{l}\text { Mean } \\
\text { Mean } \\
\text { Std. }\end{array}$} & $\begin{array}{l}\text { Diff. } \\
\text { Dev. }\end{array}$ & $\begin{array}{l}143.00 \\
-1.5 \\
2.8\end{array}$ & $\begin{array}{l}142.29 \\
-3.6 \\
5.5\end{array}$ & $\begin{array}{c}142.43 \\
-2.1 \\
2.4\end{array}$ & $\begin{array}{l}143.43 \\
-0.6 \\
2.9\end{array}$ & $\begin{array}{l}144.86 \\
0.4 \\
1.6\end{array}$ \\
\hline & & $\begin{array}{l}143.44 \\
140.63 \\
146.25 \\
140.63 \\
140.63 \\
146.25 \\
140.62\end{array}$ & $\begin{array}{l}\text { st-crui } \\
137.82 \\
143.44 \\
140.62 \\
146.26 \\
143.44 \\
143.44 \\
140.62\end{array}$ & $\begin{array}{l}\text { turntable } \\
\begin{array}{l}137.81 \\
140.63 \\
143.44 \\
143.43 \\
143.44 \\
143.44 \\
\text { no data }\end{array}\end{array}$ & $\begin{array}{l}\text { tests } \\
\begin{array}{l}146.26 \\
143.44 \\
143.44 \\
146.26 \\
146.25 \\
140.63 \\
146.26\end{array}\end{array}$ & $\begin{array}{l}143.44 \\
140.63 \\
143.25 \\
140.63 \\
140.63 \\
146.25 \\
146.26\end{array}$ \\
\hline $\begin{array}{l}\text { Mean } \\
\text { Mean } \\
\text { Std. }\end{array}$ & $\begin{array}{l}\text { Diff. } \\
\text { Dev. }\end{array}$ & $\begin{array}{r}142.63 \\
-1.86 \\
2.47\end{array}$ & $\begin{array}{r}142.23 \\
-2.27 \\
2.54\end{array}$ & $\begin{array}{r}142.03 \\
-2.47 \\
2.15\end{array}$ & $\begin{array}{r}144.65 \\
0.15 \\
2.05\end{array}$ & $\begin{array}{r}143.44 \\
-1.06 \\
2.61\end{array}$ \\
\hline \multicolumn{7}{|c|}{$\begin{array}{l}\text { Mean = average of seven values } \\
\text { Diff. = (VAWR - Landmark heading) } \\
\text { Mean Diff. = mean of seven Diff. } \\
\text { Std. Dev. = standard deviation of }\end{array}$} \\
\hline
\end{tabular}


charts. The vertical variation of the magnetic field is within about one degree measured at elevations of $3.5,5$ and 10 feet, the height of the VAWR compass. The buoys were mounted each in turn on a wooden and masonite turntable, and the direction of the flagpole at the end of the National Marine Fisheries Laboratory pier was measured from six buoy orientations. The flagpole target is about 285 meters from the test position. Each data set contains seven records as the first position is repeated at the end.

The buoys were placed on the turntable and positioned so the three legs of the tower and the angle bisecting the legs were more or less aligned in turn with the flagpole. At each of these six positions, the wind vane was aligned to the flagpole by eye and locked in position for one hour while the data were recorded on the VAWR tape. On each data record (eight per hour), the compass and the vane-follower position were logged separately in 7-bit grey code. The compass and vane positions are added to obtain the wind vane direction in oceanographic current convention (i.e. the direction of flow from the north is. $180^{\circ}$ ).

Algebraically summing the possible contributing errors, the maximum allowable instrumental error is six bits, and each binary bit equals $2.81^{\circ}$, for a total possible error of $\pm 16.9^{\circ}$. The RMS of the errors is $7.4^{\circ}$. The compass and vane-follower each have a linearity error specification of \pm 2 bits, and each has a possible alignment error of \pm 1 bit. There is some calibration site error, but it is considered to be less than one bit. If site error is added, however, it results in a worse case possible variation of \pm 7 bits or $\pm 19.7^{\circ}$ and the RMS is $7.9^{\circ}$.

The total variation in the measured direction was 3 bits (8. $4^{\circ}$ ) for all 70 test positions ( 5 buoys, pre- and postcruise tests with seven positions per test). The 
repeatability, maximum difference in the mean direction between pre- and post-cruise tests, was $1.5^{\circ}$, less than 1 bit. The magnetic heading of the flagpole from the test site is $324.5^{\circ}\left(324.5^{\circ}-180^{\circ}=144.5^{\circ}\right.$ after the adjustment for oceanographic convention of flow direction is applied).

\section{Temperatures}

To conserve battery power, air and water temperature are measured with similar thermistor sensors and shared (multiplexed) circuits in the VAWR. Circuits developed and built at WHOI as a modification to the original VACM design allow the measurement of temperature, pressure and other variables with minimal increase in the power consumption. The VAWR uses these circuits from the Multiplexed VACM (MX$\mathrm{VACM}$ ) to measure sea and air temperature.

Air temperature is sensed at about 3 meters height above the sea surface using a thermistor sensor which is protected in an acetal housing installed in a radiation shield. Water temperature is measured at nominal one meter depth under the buoy with a similar sensor installed in a pressure protected aluminum enclosure strapped to the stiff bridle. The electrical cable runs through connectors in the discus buoy hull and into the VAWR electronics package.

Specifications :

$$
\text { Air Temperature }
$$

Range

Accuracy

Resolution

Thermal time constant

$$
\begin{aligned}
& -10 \text { to }+35^{\circ} \mathrm{C} \\
& 0.2^{\circ} \mathrm{C} \text { (Winds }>2 \mathrm{~m} / \mathrm{s} \text { ) } \\
& 0.00012^{\circ} \mathrm{C} \\
& 150 \text { seconds }
\end{aligned}
$$


Sea Temperature

Range

Accuracy

Resolution

Thermal time constant
-5 to $+38^{\circ} \mathrm{C}$

$0.005^{\circ} \mathrm{C}$

$0.00012^{\circ} \mathrm{C}$

7 seconds

Thermal time constant is measured by subjecting the sensor in its housing to a step change in temperature of several degrees in a water bath and observing the sensor response (for example, see Figure 6, page 25).

The air temperature sensor radiation shield is a Thallertype multiple plate design by Gill (1979). Consisting of nine parallel plates $12.7 \mathrm{~cm}$. (5 inches) in diameter, the stack is about $10 \mathrm{~cm}$. high overall. The design allows free flow of air but protects the sensor from direct and reflected sunlight from all angles. Payne (1987) describes comparison tests between these shields and an aspirated standard shield. A vane is attached to the buoy tower in an effort to cause the wind to steer the buoy and keep the meteorological sensors on the windward side.

VAWR temperature data are decoded by combining precision calibrations of individual thermistors with an instrument calibration done by substituting known resistance values in place of the thermistor at the input to the temperature measuring circuits. The technique allows interchangeability of slightly dissimilar sensors without sacrifice in accuracy of the measurement. For maximum accuracy, the VAWR circuit calibrations require a parameter change in the data processing algorithm. This refinement is needed especially when a modification changes the effective circuit impedance; the addition of a cable to reach the sea or air temperature 
sensors from the sealed electronic housing is such a modification.

Constant-temperature bath tests were conducted on the temperature sensors after the field experiment. Results of the comparisons between the bath temperatures as measured by the standard thermometer and that measured by the VAWRs are given in Table VIII.

The insulating jacket on the electrical cable to the sea temperature sensor on VAWR 121 (Buoy B) was found to be cut after the poor bath calibration results. It is assumed that the data are not good throughout the FASINEX experiment.

The VAWR sea surface temperature measurements made at 0.7 meter depth under the buoys are systematically lower than the current meter temperatures by approximately $0.025^{\circ} \mathrm{C}$ during times when the water is well mixed to 80 meters depth. The reasons for this are unknown, and tests are being conducted to determine if the effect is instrumental or oceanic. A later deployment of a VAWR on a 3-meter discus buoy to the north of the FASINEX area in an office of Naval Research funded program called BIOWATT showed a similar difference between sensors at 0.7 and 1.7 meters below the buoy. Histograms of the differences for the FASINEX moorings and the BIOWATT test are given in Figures 9 and 10. These graphs show the predominance of the $0.025^{\circ}$ difference between the 0.7 meter and the deeper measurements.

\section{E. Insolation}

VAWR insolation measurements are made with Eppley (The Eppley Laboratory, Inc., Newport, Rhode Island) model 8-48 pyranometers. These transducers are sensitive to incident 
Table VIII

VAWR Bath Test Results

Sea Temperature Sensor minus Bath Temperature (Degrees C)

VAWR

\begin{tabular}{llllll}
5 & 10 & 15 & 20 & 25 & 30 \\
\hline
\end{tabular}

161

$+.0002+.0006+.0014+.0052+.0046$ *

$121+.0567+.0450+.0338+.0276+.0225$ *

$\begin{array}{llllll}706 & -.0023 & -.0040 & -.0037 & -.0021 & +.0027 \quad *\end{array}$

$184 \quad-.0078-.0063-.0044-.0026-.0028 \quad$ *

$\begin{array}{lllllll}705 & -.0031 & -.0042 & -.0026 & -.0008 & -.0046 \quad *\end{array}$

* The 30 degree bath temperature was out of range.

Air Temperature Sensor minus Bath Temperature (Degrees C)

$\begin{array}{lllllll}161 & -.0174 & -.0079 & -.0109 & -.0102 & -.0101 & -.0133 \\ 121 & -.0074 & +.0023 & +.0019 & +.0005 & +.0000 & +.0032 \\ 706 & +.0105 & +.0093 & +.0074 & +.0069 & +.0054 & +.0048 \\ 184 & -.0152 & -.0080 & -.0101 & -.0106 & -.0114 & -.0120 \\ 705 & -.0002 & -.0044 & -.0023 & -.0019 & & -.0002\end{array}$

VAWR Temperature Bath Tests

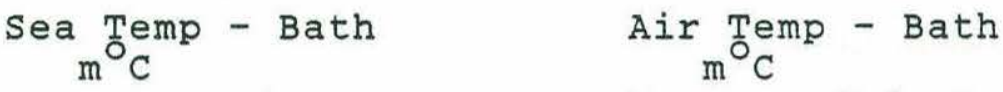

VAWR Mean Std. Dev. Mean std. Dev.

$\begin{array}{rrrrr}161 & 2.4 & 2.1 & -11.6 & 3.8 \\ 121 & 37.1 & 12.3 & 0.1 & 3.5 \\ 706 & 3.0 & 0.8 & 7.38 & 2.0 \\ 184 & -1.9 & 2.4 & -11.2 & 2.2 \\ 705 & -3.1 & 1.3 & -1.8 & 1.6\end{array}$




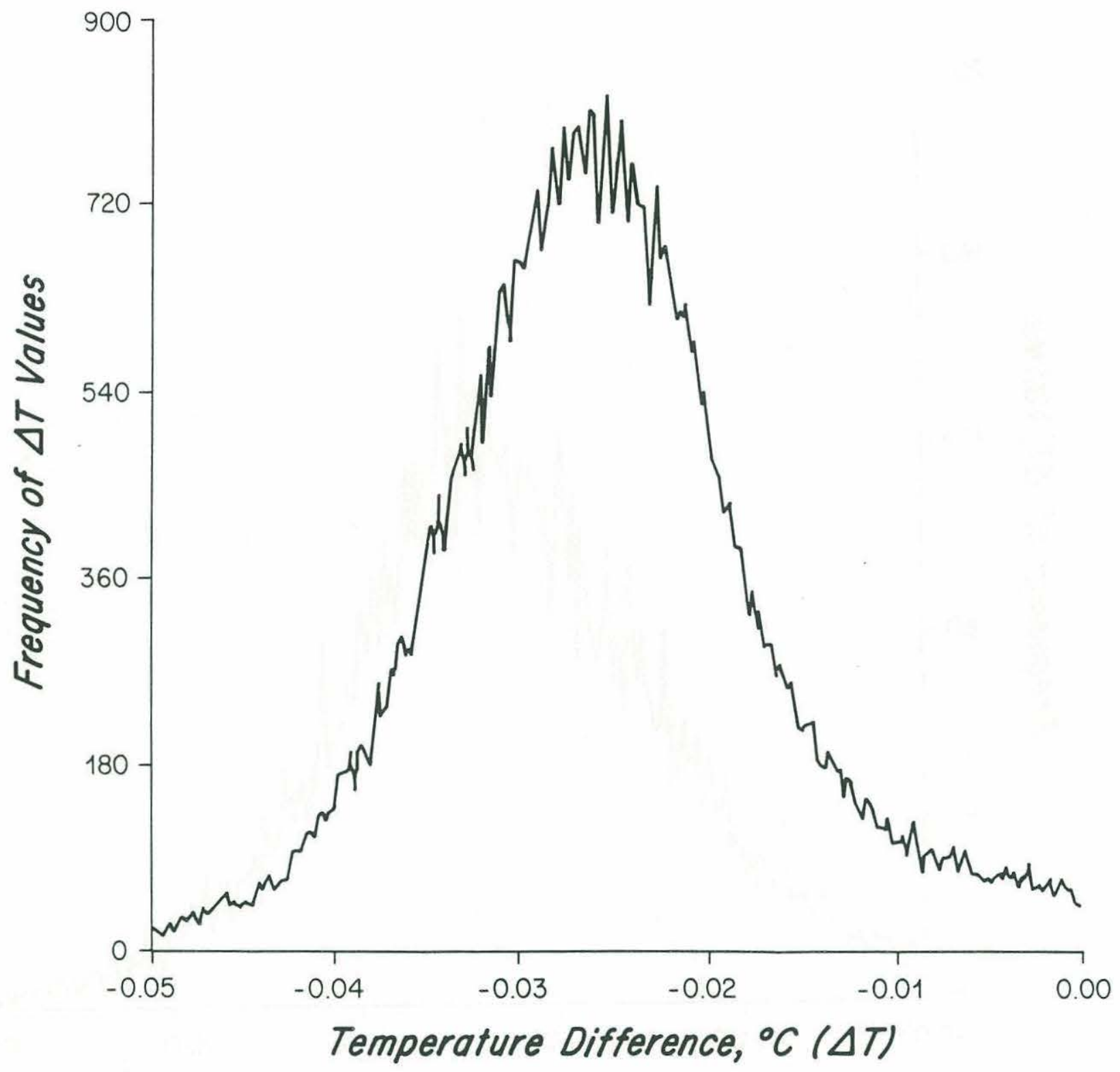

Figure 9. Temperature difference histogram: VAWR sea temperature @ $0.7 \mathrm{~m}$ deep $(0.25 \mathrm{~m}$ below buoy hull) minus tenmeter deep VMCM. Total of the values from four FASINEX moorings 


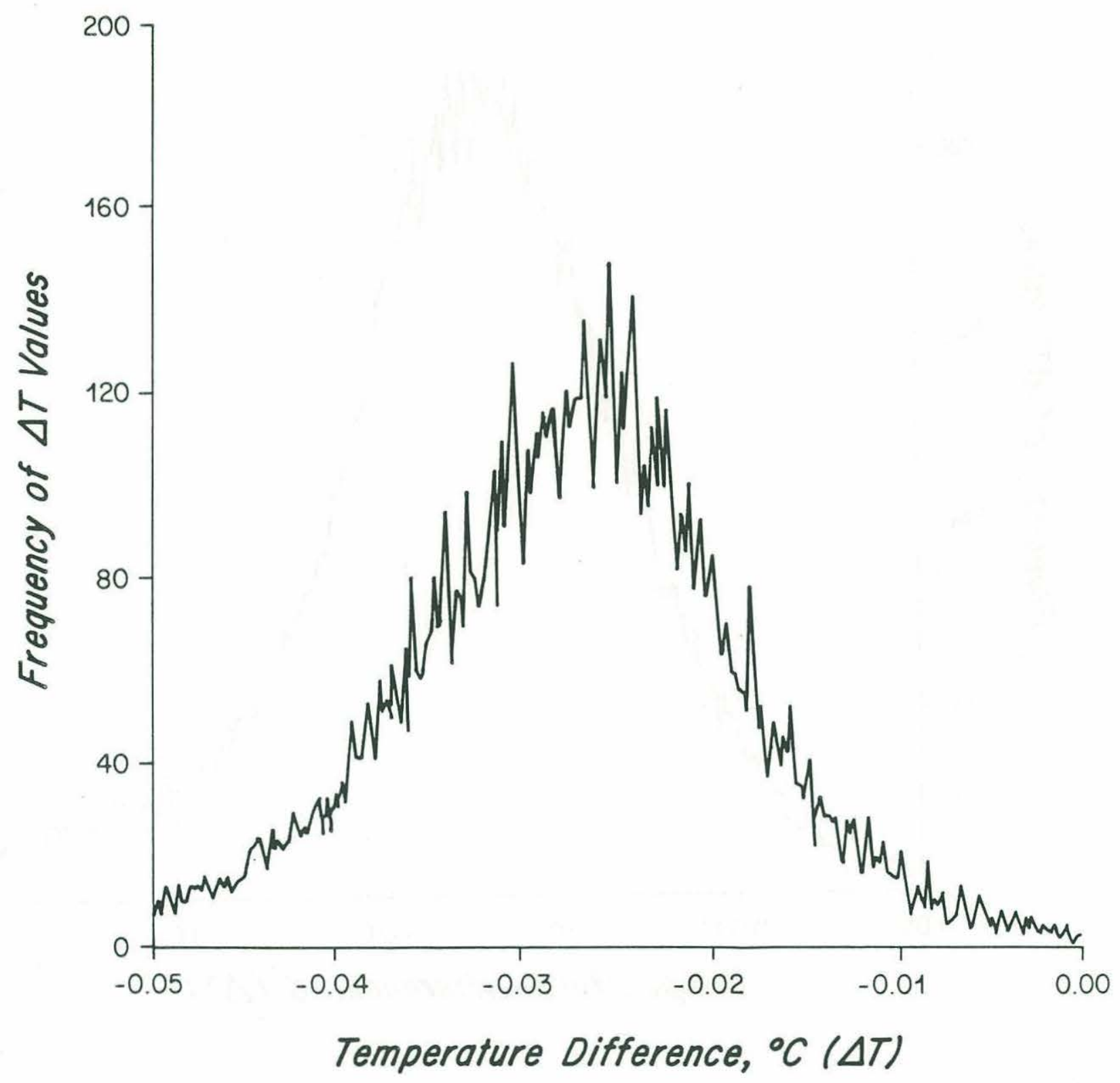

Figure 10. Temperature difference histogram: VAWR sea temperature @ $0.7 \mathrm{~m}$ deep $(0.25 \mathrm{~m}$ below buoy hull) minus VAWR sea temperature @ $1.7 \mathrm{~m}$ depth (1.25 $\mathrm{m}$ below the buoy hull) for one BIOWATT surface mooring deployment of three months duration (February to May 1987) 
global solar radiation in the 0.35 to 2.5 micron range. The temperature difference between a blackened surface and an adjacent white surface both exposed to solar radiation is measured with an array of thermocouple junctions. The low level dc output signal from the thermopile is amplified and used to modulate a voltage-to-frequency converter which provides continuous input to an electronic counter. The total counts for a recording interval are stored on magnetic tape at the end of each interval (for FASINEx, the recording interval was 225 seconds).

Manufacturer's specifications for the Eppley pyranometer:

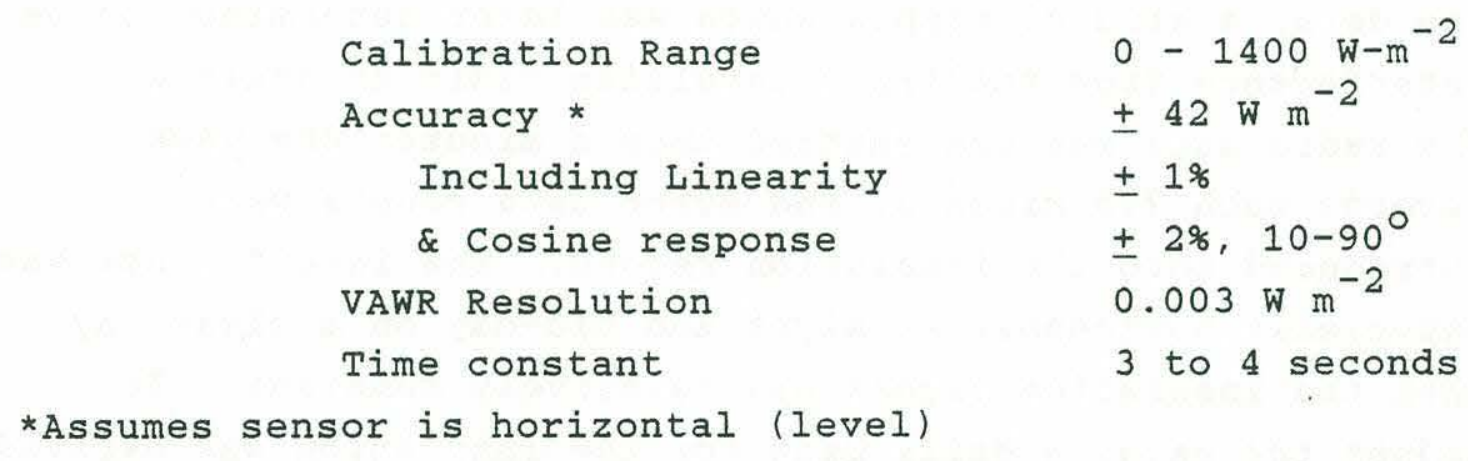

The sensors are mounted on the buoy tower in a fixed position with minimum obstruction by other sensors about 3.5 meters above the water. Specified pyranometer errors do not include the effects of the off-level condition evident when the instruments are rigidly mounted on buoys. The magnitude of off-level errors depends on the time of day, time of the year, and latitude and can be quite large, greater than $15 \%$ for buoy tilts of about $10^{\circ}$ (Katsaros and DeVault, 1986). Although buoy motion has not been measured directly, it is assumed that the mean inclination is small and thus negligible compared to other errors. Buoy tilts are believed to average nearly to zero over periods of time 
which are large compared to the motion periods. Some studies of this motion are reported by Payne (1988).

Pre- and Post-Cruise Calibrations

The five FASINEX pyranometers were re-calibrated at the end of the field work, ten months after the pre-cruise calibrations. The largest difference was a change of $2.3 \%$. The average change for the five was $0.0 \%$; the standard deviation was $1.5 \%$.

The FASINEX time series of insolation showed a "noise" on the data, a kind of ripple which was later determined to be interference from the Argos satellite radio transmitter. The radio data was transmitted once a minute; the VAWR records each 7.5 minutes, and error data counts were introduced into the insolation record. The interference was especially noticeable at night and mid-day on a clear day when the insolation signal was relatively constant. To adjust the data, a daily bias for the insolation was derived from the previous and following night-time value. The daily bias calculated in this manner included not only the interference from the Argos transmitter but also an electronic bias term intentionally added to prevent negative values during very dark periods, and any variation over time that occurred in either of these errors. The bias, approximately $30 \mathrm{~W} / \mathrm{m}^{2}$, thus calculated was subtracted from each data record for that day.

F. Barometric Pressure

Changes in barometric pressure were detected by a model 215AS (or 215-AW) quartz crystal transducer manufactured by Paroscientific Inc., Redmond, Washington. Designed to 
operate over a range of 0 to 1034 millibars absolute, the digiquartz sensor is the sensitive element in an oscillator circuit. The output frequency is stored and recorded as part of the VAWR data record. The sensor housing includes a parallel-plate static pressure port designed by G. Gill (1976) which reduces the effects of wind to less than 0.3 mbar for wind speeds less than $20 \mathrm{~m} / \mathrm{s}$ and buoy attitude less than 10 degrees from horizontal.

Specifications:

Calibration range

Sensor calibration accuracy:

Estimated system accuracy:

Resolution:

Temp sensitivity
0 - 1034 millibars

$\pm 0.015 \%, \pm 0.15$ millibars \pm 0.5 millibars

0.1 millibars

$0.0007 \% /{ }^{\circ} \mathrm{C}$ *

* See comments below.

The transducer power is switched on midway through the basic VAWR recording interval; then, following a short settling time, data are stored during a 2.6 second measuring period.

The transducers were recalibrated after the experiment and the data compared to calibration data taken before FASINEX. An apparent drift over time had occurred. Paroscientific later stated that the problem was well understood and that the drift could be modeled as linear drift. A correction to the sea data for each transducer was made in the form of a bias and slope added to the decoded pressure. The correction is roughly 1.5 mbar per year for four of the five sensors used in FASINEX. These four are of an early design with an epoxy seal (Model 215-AS). Transducers are now manufactured with a welded seal (Model 215-AW) and exhibit a much lower drift rate. 
From the pre-deployment (November 18, 1985) calibrations, if $\mathrm{P}$ is the decoded pressure, then a bias correction, $\mathrm{B}$, in mbars and a slope, $M$, in mbars/day is added to each record and a corrected pressure, PC, calculated. The values used in the model are tabulated below.

$$
\mathrm{PC}=\mathrm{P}+\mathrm{B}+\mathrm{M} \mathrm{X} \text { (days since setting). }
$$

$\begin{array}{cll}\text { BUOY } & \text { BIAS } & \text { SLOPE } \\ \text { D } & \text { B }=0.433 \text { mbar } & \text { M }=0.0059 \mathrm{mbar} / \text { day } \\ \text { B } & \text { B }=0.345 & \text { M }=0.0050 \\ \text { A } & \text { B }=0.313 & M=0.0046 \\ \text { E } & \text { B }=0.276 & M=0.0039 \\ \text { C } & \text { B }=0.027 & \text { M }=0.0005\end{array}$

Comparisons between WHOI and Paroscientific subsequent recalibrations revealed large variations in the data and a temperature sensitivity of roughly $0.3 \mathrm{mbar}$ per ${ }^{\circ} \mathrm{C}$ was discovered. The temporal and thermal characteristic of the instability was such that correction was not deemed possible. Buoy $C$ had a later Model 215-AW sensor and did not exhibit the instabilities of the other four sensors.

For comparison, times when the buoys were assembled on the dock were chosen and the pressure records were compared. Two dates were chosen: one before the deployment and a second after the pick-up cruise. Table IX lists the VAWR pressure comparisons for these dates and also notes pressures measured at stations north and south of Woods Hole at the time. There is no estimation of accuracy for these data. Obviously the Woods Hole Coast Guard Station data is suspect. 
TABLE IX

Atmospheric Pressure Comparisons

Test data for $1 \mathrm{Jan} 86,05: 49 \mathrm{Z}:$ Temp $=0.0^{\circ} \mathrm{C}, \pm .1$ [Values derived using slope and bias corrections, see text

\begin{tabular}{lrc} 
BUOY & Sensor \# & Pressure \\
D & 12874 & 1007.88 \\
B & 12877 & 1009.46 \\
A & 12864 & 1008.76 \\
E & 16768 & 1008.91 \\
C & 17327 & 1004.91 \\
\multicolumn{2}{l}{ mean $=$} & 1007.98 \\
1 sigma $=$ & 1.62
\end{tabular}

Test data for 7 August $87,1256 \mathrm{z} .:$ Temp $=23.2^{\circ} \mathrm{C}, \pm .5$

$\begin{array}{lcl}\text { BUOY } & \text { Sensor \# } & \text { Pressure } \\ \text { D } & 12874 & 1018.61 \\ \text { B } & 12877 & 1018.67 \\ \text { A } & 12864 & 1018.38 \\ \text { E } & 16768 & 1018.51 \\ \text { C } & 17327 & 1018.51\end{array}$

$$
\text { mean }=1018.54
$$

1 sigma $=0.10$

August 7, 1986, $1300 \mathrm{z}$ Comparisons with other sources of absolute pressure data, corrected to WHOI dock sensor elevations (21 ft.).

WHOI Lobby

Otis Weather station, 29.950" (1) $131 \mathrm{ft}$.

Menemsha Coast Guard Station, 30.11" @ 26 ft. 1019.50

Woods Hole Coast Guard Station, 30.85" @ 40 ft. 1045 


\section{G. Relative Humidity}

Because of the difficulty in making reliable and accurate measurements, and anticipating special accuracy requirements in the FASINEX project, a circuit was developed to attempt to improve relative humidity data accuracy and reliability. The circuit, as supplied by Vaisala with the "Humicap" sensor element, is a binary oscillator circuit, and the output is demodulated to produce a dc signal. These data are then converted for digital recording with an analog-todigital converter. From previous experience, the Vaisala circuit reliability was questionable and required inordinate amounts of power for our application. The Vaisala circuits were replaced with a low-power oscillator and digital counter whose output is stored and recorded with standard logic devices in the VAWR.

Design goal specifications:

$\begin{array}{ll}\text { Range } & 0 \text { to } 100 \% \mathrm{RH} \\ \text { Accuracy } & 1 \% \mathrm{RH} \\ \text { Resolution } & 0.05 \% \mathrm{RH}\end{array}$

The oscillator circuits are themselves sensitive to temperature variations, so a thermistor was added as part of the resistive component in the $\mathrm{RC}$ feedback network to compensate for the thermal effects. The Vaisala Humicap element is a part of the capacitive component in the oscillator. This technique allows the output frequency to vary with the capacitive changes in the Humicap element resulting from changes in relative humidity, and to be relatively insensitive to changes in the ambient temperature. To test the temperature sensitivity of the 
sensors and new circuits, the units were assembled and tested at various temperatures in the confined atmospheres above three different saturated salt solutions, LiCl, $\mathrm{K}_{2} \mathrm{SO}_{4}$ ' and $\mathrm{NaCl}$. Units were accepted for use that remained within $1 \%$ relative humidity over the range of $5^{\circ} \mathrm{C}$ to $25^{\circ} \mathrm{C}$, and within $3 \%$ relative humidity over the range of $10 \%$ to $90 \% \mathrm{RH}$ over the same temperature range. Exposure to the salts during the testing is believed to have contributed to later premature failure of some elements.

The Humicap elements were thus matched to the circuits, and this sensor assembly was calibrated at various humidities and then installed on the VAWR. A dockside system test to compare sensors was run before and after the sea experiment with independent calibration points measured periodically with a Bendix psychrometer Model 566 during the system tests. Comparisons conducted before the deployment are recorded on the data tape, and because the deployed array was geographically small, comparisons of the time series of sea data are useful because they are very similar.

There were ten Humicap sensor elements used in FASINEX: one on each VAWR with WHOI circuitry, and one in each of the MR relative humidity sensors which had Vaisala circuitry. overall, the Humicap sensors of both types performed poorly; six of the ten sensors had failed before the post-cruise tests. Of the remaining four, two were reasonably stable and in agreement with the pre-cruise calibrations within 5\% RH over most of the range. The other two had shifted calibration from $10 \%$ to $100 \% \mathrm{RH}$. There is strong evidence that the reliability problem is with the sensing element rather than the circuits.

Based on post-cruise calibrations, measurements from one VAWR (Buoy F4) and one MR (Buoy F6) are reliable data. Field data comparisons show the relative humidity data from 
Buoys F6 and F4 tracking within about $3 \%$ of each other. However, VAWR data from Buoy F6 differs from the MR data on the same buoy by about $5 \%$.

At the end of the experiment, several Humicap element electrical leads had failed, apparently from corrosion, and there was other evidence of severe corrosion. While at sea, the elements were covered with a Gor-Tex ${ }^{R}$ shield to prevent exposure to salts while allowing exposure to water vapor in the air. It is now believed that continued exposure to the three salt atmospheres used for the calibration tests resulted in severe corrosion of the elements themselves. Failure of nitrile rubber (Buna N) O-rings which were used to attach the Gor-Tex ${ }^{R}$ shields allowed the shields to fall off at sea and, undoubtedly, contributed to the problem. The MR shields of similar design are held in place with silicone rubber o-rings which did not fail.

During processing of the relative humidity data, linear adjustments were made to the basic time series based on drifts: (1) calculated from pre- and post-deployment calibrations; (2) estimated from shipboard observations; and (3) based on redundant measurements made at a given buoy.

Adjustments made to the VAWR data were linear drifts between the two bias points listed below.

Buoy January Bias June Bias

$\begin{array}{lll}\text { F2 } & -6 \% & -6 \% \\ \text { F4 } & -6 \% & -6 \% \\ \text { F6 } & -6 \% & -9 \% \\ \text { F8 } & -3 \% & -12 \%\end{array}$

F10 No Data 
A. Introduction

Each surface mooring in the FASINEX array had two VACMs (vector-averaging current meters) in the near-surface current meter complement. Standard WHOI VACMs, these also measure and record temperature. WHOI VACMs differ from offthe-shelf current meters primarily in sensor bearing design. The WHOI bearings are nickel-binder tungșten carbide pivots and thrust bearings used in conjunction with Delrin ${ }^{R}$ radial bearings. The pivots are .125 inch in diameter, and there is .0065 inch radial clearance.

Temperature is measured in a VACM with a thermistor sensor mounted to the lower deck or the circuit chassis. The chassis is thermally connected to the sea water through the pressure housing lower plate. Circuits in the VACMi convert the resistance of the thermistor to a frequency modulated signal whose resistance-frequency characteristic is known through calibration procedures. The calibrated thermistor Temperature-Resistance ( $T-R)$ characteristic is known within about $0.002^{\circ} \mathrm{C}$. The VACM temperature circuitry measures over the range of $-5^{\circ}$ to $+30^{\circ} \mathrm{C}$, and is accurate to $.005^{\circ} \mathrm{C}$ (Payne et. al., 1976). For 900 second recording interval the resolution is $0.0002^{\circ} \mathrm{C}$; the thermal time constant of an assembled VACM lower plate is 100 seconds.

Temperature data are decoded by combining precision thermistor calibrations made in a constant temperature bath, with a VACM circuit calibration done by substituting known resistance values in place of the thermistor at the input to the temperature measuring electronics. This technique allows the interchangeability of slightly dissimilar sensors without sacrificing measurement accuracy. 


\section{B. System Temperature Tests}

The five FASINEX surface moorings had VACMs and VMCMs spaced 10 meters apart vertically starting at 10 meters depth. A total of ten VACMs was used in the upper ocean; two on each of the five moorings. At times during the experiment the five current meters nearest the surface were all in wellmixed water of very nearly the same absolute temperature. Comparison of the temperature data at these times provides a good check on system performance of the two types of instruments.

After FASINEX, as a part of post-cruise testing, the temperature sensors were placed in a constant-temperature bath and the bath temperature was recorded by each VACM. The bath temperature measured with a standard thermometer and the temperature from the VACM recorded data were compared. The difference errors were larger than expected from some instruments, so the thermal stability of the VACM temperature circuits was studied. These tests revealed that some of the VACM circuits exhibited a temperature dependence. Because the electronics were found to be temperature sensitive, the bath data were reprocessed using post-cruise circuit calibrations made at temperatures near the ocean ambient. The results of comparisons after recalibrating the circuits has been tabulated in Table $\mathrm{x}$. There was a problem with $\mathrm{V}-0680$ and the bath comparison could not be made.

In addition, tests were run to confirm that the errors were indeed thermal and not temporal drift in the circuits. Subsequent testing of all the VACM temperature circuits revealed a temperature sensitive amplifier in some of the circuits. The faulty circuits have been repaired or removed from service. 
Table X

VACM System Temperature Tests

$\underline{\text { VACM }}$

5104

5113

5114

0661

0680

0712

0716

0717

0718

0721
Bath Temperature minus VACM

$$
.0004
$$

.0008

$-.0016$

.0023

.0015

.0006

.0002

.0005

.0002

Comparison of differences in true bath temperature and that recorded by the VACMs during post-cruise system bath tests. 
V. Acknowledgements

The preparation of the FASINEX moored array and subsequent data analysis involved nearly everyone in the WHOI Buoy Group. It was by no means a simple task; however, the "can do" attitude exhibited throughout the year-long preparations made the project a real team effort. Thank you to all members of the Buoy Group who contributed to the success of the experiment.

Special thanks are extended to Joe Poirier (current meter shop supervisor) whose unending attention to detail contributed to the $96 \%$ data return from the moored instrumentation on and below the buoy. As we have come to expect, the mooring work was once again flawlessly executed by the coordinated efforts of Dave Simoneau (mooring shop supervisor) and Will Ostrom. Working with these people throughout FASINEX made the project fun. A special thank you to Bob weller (FASINEX principal investigator) for his unassuming inquiries into procedures and techniques. In response to his questions, the Buoy Group took a closer look at the problems and in many instances fine-tuned its techniques.

The authors also thank Penny Foster, Barbara Gaffron and Jane Louise for their help with the preparation of this report and thanks to Nancy Pennington for her help with the graphics.

Funding for this work was provided by the office of Naval Research under Contract No. N00014-84-C-0134, NR 083-400. 
VI. References

Beardsley, Robert C., 1982. A comparison of the VACM and the new EG\&G VMCM on a surface mooring in CODE-1. Journal of Geophysical Research, 92(C2), 1845-1859

Dean, Jerome P., and Robert C. Beardsley, 1988 A vector averaging wind recorder (VAWR) system for surface meteorological measurements in CODE. Woods Hole Oceanographic Institution, Technical Report, WHOI-8820, $68 \mathrm{pp}$.

Dexter, Stephen C., John D. Milliman and William J. Schmitz, 1975: Mineral deposition in current meter bearings. Deep Sea Research, 22, 703-706.

Gill, Gerald C., 1976: Development and testing of a nomoving-parts static pressure inlet for use on ocean buoys. Report on research sponsored by the NOAA Data office, Bay St. Louis, Michigan, 43 pp., 48 figs.

Gill, Gerald C., 1979: Development of a small rugged radiation shield for air temperature measurements on drifting buoys. Report on research sponsored by the NOAA Data Office, Bay St. Louis, Mississippi, 23 pp, 17 figures.

Katsaros, Kristina B. and John E. DeVault, 1986: On irradiance measurement errors at sea due to tilt of pyranometers. Journal of Atmospheric and Oceanic Technology, 3, 740-746.

LaQue, Francis L., 1975: Marine corrosion, John Wiley and Sons, New York, $81 \mathrm{pp}$. 
MacCready, P.B. Jr., and H. R. Rex, 1964: Response characteristics and meteorological utilization of propeller and vane wind sensors. Journal of Applied Meteorology, 3, 182-193.

Payne, Richard E., 1974, A buoy mounted meteorological recording package. Woods Hole Oceanographic Institution Technical Report, WHOI-74-40, $31 \mathrm{pp}$.

Payne, Richard E., 1987: Air temperature shield test. Woods Hole Oceanographic Institution Technical Report, WHOI$87-40,22 \mathrm{pp}$.

Payne, Richard E., 1988: The MR, a meteorological sensing, recording and telemetering package for use on moored buoys. Journal of Atmospheric and Oceanic Technology, 5, 286-297.

Payne, Richard E., Alvin L. Bradshaw, Jerome P. Dean, and Karl E. Schleicher, 1976: Accuracy of temperature measurements with the VACM. Woods Hole Oceanographic Institution Technical Report, WHOI-76-94, $78 \mathrm{pp}$.

Stage Steven A., and Robert A Weller, 1985. The frontal airsea interaction experiment (FASINEX); Part I: Background and objectives. Bulletin of the American Meteorological Society, 66, 1511-1520.

Stage Steven A., and Robert A Weller, 1986. The frontal airsea interaction experiment (FASINEX); Part I: Experimental plan. Bulletin of the American Meteorological Society, 67, 16-20.

Weller, R. A. and R. E. Davis, 1980. A vector measuring current meter. Deep-Sea Research, 27A, 565-582. 
VII. Appendix

After FASINEX (Frontal Air-Sea INteraction Experiment) the VMCM (Vector Measuring Current Meter) temperatures were corrected for thermistor self-heating. Self-heating is the term given the temperature increase in the sensor resulting from the dissipation of the excitation power.

Thermistor calibration procedures for the VACM (Vector Averaging Current Meter) specify that thermistors be calibrated at the same power level as that continuously applied in the current meter. As the self-heating varies somewhat from thermistor to thermistor, this procedure makes it unnecessary to measure the self-heating effect and to apply a self-heating correction when decoding the field data.

In FASINEX all the thermistors were calibrated using power levels applied in the VACM, but they were used in both VACMs and VMCMs. The circuitry in the VMCM switches the power to the thermistor for a very short period of time during the measurement; and as a result there is negligible self-heating of the sensor. However, use of the calibration constants calculated for the VACM will result in an error if used for decoding VMCM data. The error can be determined by a test done in the constanttemperature calibration bath, and a correction can be made to the data.

Electrical power loss in a resistive element is dissipated as heat, causing the temperature of the resistive device to rise. When the element is a thermistor temperature sensor, this effect is the self-heating, and can be measured as follows. The power equation can be written

$$
P=E^{2} / R,
$$

where $P$ is the power, $E$ is the excitation voltage and $R$ is the resistance of the thermistor at a given temperature. If the power is doubled, $2 \mathrm{P}$, the self-heating is doubled. The temperature change in the sensor resulting from doubling the power will be the self-heating error.

$$
2 \mathrm{P}=(1.414 \mathrm{E})^{2} / \mathrm{R} \text {. }
$$

The power is doubled by increasing the excitation voltage by 1.414 
(the square root of 2). In a test conducted in a constant temperature bath, the thermistor excitation voltage was increased by a factor of 1.414. The increase in the sensor temperature is equal to the self-heating error. The result of these tests on ten FASINEX VMCM thermistors made at six temperatures is tabulated below.

$\begin{array}{cc}\begin{array}{c}\text { Temperature } \\ { }^{\circ} \mathrm{C}\end{array} & \begin{array}{c}\text { self-heating }\left(\mathrm{m}^{\circ} \mathrm{C}\right) \\ \text { average }( \pm 1 \text { sigma })\end{array} \\ 5 & 10.06 \pm .92 \\ 10 & 9.58 \pm .82 \\ 15 & 9.85 \pm .71 \\ 20 & 10.29 \pm .76 \\ 25 & 10.37 \pm .76 \\ 30 & 9.13 \pm .76 \\ & \text { Ave. }=10.05 \pm .79\end{array}$


DOCUMENT LIBRARY

August 9, 1988

\section{Distribution List for Technical Report Exchange}

Attn: Stella Sanchez-Wade

Documents Section

Scripps Institution of Oceanography

Library, Mail Code C-075C

La Jolla, CA 92093

Hancock Library of Biology \& Oceanography

Alan Hancock Laboratory

University of Southern California

University Park

Los Angeles, CA 90089-0371

Gifts \& Exchanges

Library

Bedford Institute of Oceanography

P.O. Box 1006

Dartmouth, NS, B2Y 4A2, CANADA

Office of the International

Ice Patrol

c/o Coast Guard R \& D Center

Avery Point

Groton, CT 06340

Library

Physical Oceanographic Laboratory

Nova University

8000 N. Ocean Drive

Dania, FL 33304

NOAA/EDIS Miami Library Center

4301 Rickenbacker Causeway

Miami, FL 33149

\section{Library}

Skidaway Institute of Oceanography

P.O. Box 13687

Savannah, GA 31416

Institute of Geophysics

University of Hawaii

Library Room 252

2525 Correa Road

Honolulu, HI 96822

Library

Chesapeake Bay Institute

4800 Atwell Road

Shady Side, MD 20876

MIT Libraries

Serial Journal Room 14E-210

Cambridge, MA 02139
Director, Ralph M. Parsons Laboratory

Room 48-311

MIT

Cambridge, MA 02139

Marine Resources Information Center

Building E38-320

MIT

Cambridge, MA 02139

Library

Lamont-Doherty Geological

Observatory

Colombia University

Palisades, NY 10964

Library

Serials Department

Oregon State University

Corvallis, OR 97331

Pell Marine Science Library

University of Rhode Island

Narragansett Bay Campus

Narragansett, RI 02882

Working Collection

Texas A\&M University

Dept. of Oceanography

College Station, TX 77843

Library

Virginia Institute of Marine Science

Gloucester Point, VA 23062

Fisheries-Oceanography Library

151 Oceanography Teaching Bldg.

University of Washington

Seattle, WA 98195

Library

R.S.M.A.S.

University of Miami

4600 Rickenbacker Causeway

Miami, FL 33149

Maury Oceanographic Library

Naval Oceanographic Office

Bay St. Louis

NSTL, MS 39522-5001

Marine Sciences Collection

Mayaguez Campus Library

University of Puerto Rico

Mayagues, Puerto Rico 00708 


\begin{tabular}{|c|c|c|}
\hline $\begin{array}{l}\text { REPORT DOCUMENTATION } \\
\text { PAGE }\end{array}$ & $\begin{array}{l}\text { 1. REPORT NO. } \\
\text { WHOI-89-3 }\end{array}$ & 3. Recipient's Accession No. \\
\hline \multirow{2}{*}{\multicolumn{2}{|c|}{$\begin{array}{l}\text { 4. Title and Subtitle } \\
\text { FASINEX (Frontal Air-Sea Interaction Experiment) Moored Instrumentation }\end{array}$}} & $\begin{array}{l}\text { 5. Report Date } \\
\text { February } 1989\end{array}$ \\
\hline & & 6. \\
\hline \multicolumn{2}{|c|}{$\begin{array}{l}\text { 7. Author(s) } \\
\text { Richard P. Trask, Jerome P. Dean, James R. Valdes, Craig D. Marquette }\end{array}$} & $\begin{array}{l}\text { 8. Performing Organization Rept. No. } \\
\text { WHOI-89-3 }\end{array}$ \\
\hline \multirow{2}{*}{\multicolumn{2}{|c|}{$\begin{array}{l}\text { 9. Performing Organization Name and Address } \\
\text { The Woods Hole Oceanographic Institution } \\
\text { Woods Hole, Massachusetts } 02543\end{array}$}} & 10. Project/Task/Work Unit No. \\
\hline & & $\begin{array}{l}\text { 11. Contract(C) or Grant(G) No. } \\
\text { (C) N00014-84-C-0134 } \\
\text { (G) }\end{array}$ \\
\hline \multirow{3}{*}{\multicolumn{2}{|c|}{$\begin{array}{l}\text { 12. Sponsoring Organization Name and Address } \\
\text { The Office of Naval Research } \\
\text { Environmental Sciences Directorate } \\
\text { Arlington, VA } 22217\end{array}$}} & 13. Type of Report \& Period Covered \\
\hline & & Technical Report \\
\hline & & 14. \\
\hline
\end{tabular}

15. Supplementary Notes

This report should be cited as: Woods Hole Oceanog. Inst. Tech. Rept., WHOI-89-3.

16. Abstract (Limit: 200 words)

In 1986, FASINEX a Frontal Air-Sea Interaction Experiment, a multi-investigator cooperative experiment, was conducted to study the role of horizontal variability in air-sea interaction in the persistent front formed in the subtropical convergence zone south of Bermuda. Aimed at investigating all aspects of the atmospheric and oceanic variables related to the formation and maintenance of the front, an array of meteorological and current meter moorings was deployed by the Woods Hole Oceanographic Institution Buoy Group in 5400 meters of water. Two subsurface current meter moorings were deployed in October, 1984; five surface meteorological and current meter moorings and four Profiling Current Meter (PCM) moorings were set in January 1986. All except one PCM mooring, which was lost, were recovered in June 1986. This report dicusses the extensive preparations of, and modifications to, the Woods Hole Oceanographic Institution Buoy Group instruments placed on the five surface moorings. The equipment included 30 vector measuring current meters, ten vector averaging current meters and five vector averaging wind recorders.

17. Document Analysis a. Descriptors

1. FASINEX

2. Air-Sea Interaction

3. Marine Instrumentation

b. Identifiers/Open-Ended Terms

c. COSATI Field/Group

18. Availability Statement

Approved for publication; distribution unlimited.

\begin{tabular}{|l|l|}
\hline $\begin{array}{c}\text { 19. Security Class (This Report) } \\
\text { UNCLASSIFIED }\end{array}$ & $\begin{array}{c}\text { 21. No. of Pages } \\
58\end{array}$ \\
\hline 20. Security Class (This Page) & 22. Price \\
\hline
\end{tabular}

